\title{
Views of Elementary School Children's Parents about Distance Education during the Covid-19 Pandemic *
}

Nilgün GÜNBAŞ ${ }^{* *}$

\author{
Meral GÖZÜKÜÇÜK ${ }^{* *}$
}

\begin{abstract}
Due to the Covid-19 pandemic, the Ministry of National Education of Turkey suspended face-to-face education in all the K-12 schools and initiated distance education on the Educational Information Network (EBA). Distance education has become imperative although it has not been frequently used before the pandemic. The purpose of this study was to reveal the opinions of elementary school children's parents about the distance education activities given via EBA. In a case study approach, a sample of parents ( $n=148$ ) was reached out with an easily accessible sampling method. Their views were taken on an online semistructured interview form. According to the parents, children have failure to enter EBA, to join live lessons and lack of internet. Because children are home during the pandemic, they do not follow school rules, accordingly do not study well and have motivational issues. The parents think that their children do not learn enough due to lack of individualized feedback. However, according to the parents, it is the positive side of distance education that children continue their education at home in a healthy and safe way. Children have a chance to repeat their classes and parents can follow their children's learning process during the pandemic.
\end{abstract}

Keywords: Covid-19 pandemic, Distance Education, EBA, Elementary School, Parents

\footnotetext{
* The ethics committee permission for this study was obtained from the Social and Humanities Ethics Committee of the Rectorate of Kafkas University, dated 22/05/2020 and numbered 05.

** Orcid ID: https://orcid.org/0000-0003-2578-3083, Assist. Prof. Dr., Kafkas University Department of Mathmatics Education, Turkey,ng2248@tc.columbia.edu

*** https://orcid.org/0000-0002-1620-5073 , Assist. Prof. Dr., Kafkas University Department of Elementary Education, Turkey, meralyaprak@gmail.com
} 


\section{INTRODUCTION}

Distance education, which does not require the teacher and student to be physically present in the school environment, makes it possible for education to be provided independently of time and space. Distance education, which began with correspondence education, was converted into a different form with the use of resources such as sound and video (Smaldino, Lowther, Mims \& Russell, 2015). Distance education can be conducted synchronously or asynchronously, and can offer the student the possibility to repeat subjects that he/she does not understand (Dinçer, 2006). Moreover, it can provide an environment in which teachers and students can share lesson contents and interact with each other. Although distance education was not widely used in our country before the Covid-19 pandemic, it has become essential during the pandemic period.

The Ministry of National Education (MNE) switched to distance education in elementary and secondary schools from the moment cases of Covid-19 began to be seen in Turkey. On 16th March 2020, face-to-face education was suspended, and from 23rd March onwards, distance education activities were begun so that students would not lose touch with education. For this purpose, all students from 1st grade to 12 th grade were given the opportunity for distance education both via television and in an online environment by means of the Educational Informatics Network (EBA). When distance education first began, it was carried out asynchronously by teachers specified by the MNE. Later, it continued on EBA with live broadcasts made by students' own teachers. During the Covid19 pandemic, the initiation of distance education activities is an important matter in terms of preventing students from losing touch with education. However, the majority of elementary school students are having experience of distance education for the first time. Therefore, most of their parents are also witnessing their children's education being conducted via distance learning for the first time. With regard to supporting the education of elementary school children who continue their education via distance learning due to the pandemic, greater responsibility is placed on the parents. For this reason, the views of parents related to the education that elementary school children receive through distance education during the Covid-19 pandemic are important. This study is important in terms of obtaining the views of parents of elementary school children related to distance education conducted on EBA during the pandemic, and revealing the efficiency of distance education implemented in elementary schools and any deficiencies that may exist.

\section{Distance Education}

Distance education is a platform which began with correspondence courses and which can offer richer content with today's technology (Bilgiç \& Tüzün, 2015). The provision of distance education, which has been named e-learning or digital learning over the course of time, via the internet, brings to mind those individuals who do not have the facility of internet access. However, the belief has developed that this will not pose a problem, since an increasing number of internet users are able to adapt to distance education day by day (Telli Yamamoto \& Altun, 2020). While distance education was mostly used to support 
face-to-face education, and it was used in a limited number of programmes by some universities (Şentürk, 2020), it has completely replaced face-to-face education due to the current pandemic. For this reason, the necessary measures need to be taken in terms of offering, as far as is possible, the same opportunities in distance education that face-toface education provides (interaction, motivation, feedback, etc.).

It has been concluded that students who have smartphones, tablets, computers and internet access have more positive attitudes towards distance education than those who do not have these facilities (Barış, 2015). Therefore, as a solution to situations where internet access poses a problem, the MNE, by giving regard to equality of opportunity, has provided students with free internet support for using EBA and has given priority to live broadcasts.

For distance education to be conducted successfully, teachers, students and parents must carry out their responsibilities in full (Eren \& Kaya, 2017). Completing the activities and the tasks given to them is under the student's own responsibility (Gülbahar \& Karataş, 2016). However, the quality of the activities offered to students in online learning environments affects students' ideas about these environments (Ergün \& Kurnaz, 2017). Moreover, even if teachers, students and parents are familiar with the system, this situation does not necessarily mean that distance education can be carried out successfully.

There are a number of factors that affect students' ability to participate actively in the distance education system. Among the important factors are the possibility of receiving feedback, consolidation of the lesson with examples, attention to preliminary knowledge as in face-to-face education, and provision of an interaction environment (Yalçın İncik, Topçu \& Yağlığlu, 2018). Kaysi and Aydemir (2017) reported that mutual interaction in lessons given via distance education increased students' interest in lessons and that this situation also had a positive effect on instructors. In the study by Savaş and Hamamcl (2010), it was seen that parents wished to benefit from technology for reasons such as communicating with teachers, monitoring their children's situation and obtaining information.

\section{The Educational Informatics Network (EBA)}

EBA is a free online education platform in elementary and secondary schools in Turkey. EBA is an environment which was established primarily with the aim of meeting the technological content requirements of the FATIH project, and which can be utilized by the teacher and students both in a classroom environment and anywhere outside the classroom where there is internet (Karaçorlu \& Atıcı, 2019). The MNE has updated EBA and added platforms such as e-counselling, gamification, a data matrix for books, and a video library of lessons. In addition to the content created by the MNE, EBA is enriched with content created by teachers and students. EBA makes it possible for students to do group work with their peers and to communicate with them (Saklan \& Ünal, 2019). Tuluk and Akyüz (2019) reported that children can use EBA together with their parents wherever there is internet, but that teachers needed to use it more often, and that 
although teachers recommended their students to use EBA, they did not provide the necessary motivation. Students' and parents' beliefs related to distance education affect their motivation towards the education carried out on EBA.

Interaction is a very important factor in distance education. İbicioğlu and Antalyalı (2005) concluded that even if subject content is very good, when there is an inadequate level of interaction, retention of learning cannot be achieved, and that students' perceptions regarding distance education and their levels of computer use and motivation have an effect on their success in distance education. In the study by Paydar and Doğan (2019), it is seen that $49.2 \%$ of students stated distance education to be an advantage, while $50.8 \%$ of them considered it to be a disadvantage. Knowledge of the advantages and disadvantages of distance education in general, and specifically of EBA, in using EBA, which is a distance education platform, is important in terms of utilizing this platform effectively.

\section{Advantages of Distance Education}

The most frequently mentioned advantage of distance education is reported to be its time and space flexibility (Tüysüz \& Aydın, 2007; Gümüş \& Fırat, 2016; Özgöl, Sarıkaya \& Öztürk, 2017; Cabı, 2018; Paydar \& Doğan, 2019, Sezer \& Korucu, 2019). Another advantage is that lessons can be watched again (Tüysüz \& Çümen, 2016; Çakmak \& Taşkıran, 2017; Özgöl, Sarıkaya \& Öztürk, 2017; Cabı, 2018). The advantages of EBA, which is a distance education platform used by the MNE, are stated to be the possibility to repeat a subject, consolidate the subjects, solve tests, play educational games, and watch educational videos (Tüysüz \& Çümen, 2016). Çakmak and Taşkıran (2017) reported that if collaboration between the teacher, student and parents is enabled, EBA will be more beneficial and students will be able to benefit from EBA without coming to school.

Considering that teachers are familiar with platforms like EBA and have knowledge related to technology use, and that platforms such as EBA do not require advanced knowledge of technology, it can be said that lack of experience related to distance education will not present too many obstacles for teachers (Şentürk, 2020). Moreover, if students are using the EBA platform regularly (Coşkunserçe \& İşçitürk, 2019), their motivation towards EBA is increased, their learning is supported, and time-space independence is provided, this constitutes a positive situation (Sezer \& Korucu, 2019). Considering that teachers and students remain in the position of continuing their education activities via distance education during the pandemic, it can be said that there is no significant obstacle related to operating this system during this period. As an extension of the digital student concept that is used especially nowadays, the fact that students are intimate with technology and are no strangers to accessing digital resources is an indicator that they are open to e-learning.

Due to fact that there is no compulsory attendance in distance education, and that in cases where, under normal circumstances, there will be no possibility for a great number of students to come together, the removal of the physical obstacle is another advantage of distance education (Cabı, 2018). It can be said that distance education, which can offer 
different choices in terms of content, has a positive effect on students' success and that since it can be determined according to their needs, it is suitable for student-centred learning (Tüysüz \& Aydın, 2007). Considering that distance education does not necessarily ensure opportunities such as interaction, motivation and feedback, it can be said that these features need to be included in lesson content conducted in distance education. Indeed, Koçdar, Karadeniz, Bozkurt and Büyük (2017) reported that students took very kindly to interactive lesson videos, that they understood the topic better, that they learned in a shorter time and more permanently, that they could concentrate better, and that they learned in an enjoyable way. The provision of such features as these in distance education is important in terms of the productivity of distance education.

\section{Disadvantages of Distance Education}

Due to the fact that the operation of distance education is different from that of face-toface education, problems may occur. Students who are accustomed to face-to-face education, who do not have a tablet, computer, etc., who lack technological knowledge, or who do not have internet, have difficulty in following lessons conducted in distance education (Telli Yamamoto \& Altun, 2020). It is reported that technical problems occur, especially in distance education conducted via the internet, such as with the internet connection (Karakaş \& Doğan, 2017) and failure of homework to load (Özyürek, Begde, Yavuz \& Özkan, 2016). With regard to live lessons, it is stated that problems are experienced because the quality of sound and video are poor (Gül \& Arabacl, 2018). Moreover, in the study made by Cabı (2018), it is stated that among the disadvantages of distance education are the fact that students' participation in live lessons decreases as the lessons progress, and that an adequate level of explanatory feedback cannot be given.

Regarding distance education carried out in EBA, problems such as inability to enter the system (Coşkunserçe \& İşçitürk, 2019), password problems, videos and homework in EBA content opening very slowly, and students being expelled from the system during lessons (Tüysüz \& Çümen, 2016), have been reported. It is reported in the study by Atasoy and Yiğitcan Nayir (2019) that since distance education is a situation in which students who are used to face-to-face education receive education in a different way, students cannot focus on the lessons taught in EBA, cannot listen attentively to the lessons, and, since they do not take notes in the lessons, cannot achieve permanent learning. Moreover, in Tanrikulu's (2017) study, it is stated that teachers are not able to use the content of the lessons in EBA effectively.

In addition to technical problems like access to EBA and failure to enter the mobile application, problems such as insufficient feedback, inability to socialize adequately, communication problems, and attention distraction are encountered (Sezer \& Korucu, 2019; Özgül \& Uysal, 2016; Yılmaz \& Güven, 2015, Paydar \& Doğan, 2019; İbicioğlu \& Antalyall, 2005). It is reported that attendance is not recorded in lessons taught via distance education, that distance education is inadequate especially for practical lessons, that students do not gain sufficient experience, and that there is not much interaction (Özgöl, Sarıkaya \& Öztürk, 2017). Barış (2015) states that the reason why students' 
attitudes towards distance education are low may be due to the fact that they are not in favour of distance education. Moreover, İbicioğlu and Antalyalı (2005) state that students receiving distance education for the first time have low motivation.

Bilgiç ve Tüzün (2015) consider that time-space independence, which is stated to be one of the advantages of distance education, is in fact the source of the most important problems in distance education. Indeed, the fact that students are separated from their teachers and peers and cannot communicate with them leads to a loss of motivation (Şahin et al., 2017; Özyürek, Begde, Yavuz \& Özkan, 2016). Limitations that occur in relation to interaction are reported to be a problem, especially in distance education conducted asynchronously (Taşlıbeyaz, Karaman \& Göktaş, 2014). Furthermore, it is seen that students' levels of interaction anxiety in distance education are higher than expected (Arslan \& Korkmaz, 2019).

Due to the Covid-19 pandemic, it has not been possible to conduct face-to-face education activities in elementary schools. In this study, views of elementary students' parents related to the distance education carried out via EBA during the Covid-19 pandemic have been obtained, since there is a greater need for parental support for elementary students in activities conducted via distance education, both in a technical sense and in terms of assisting learning. Moreover, parents can gain awareness in the matter of their children's education, since they witness the education that their children receive due to the fact that the lessons are conducted remotely. The aim of this study is to make recommendations related to distance education carried out with lesson recordings and live lessons via EBA, by determining their positive/negative aspects from the perspective of parents. Within this scope, in this study, answers were sought to the question, "What are the views of parents of elementary school children related to distance education activities conducted in elementary schools during the Covid-19 pandemic?" Since parental influence in education for children in elementary school is important, the results of this study are important in terms of increasing the efficiency of instruction in activities carried out via distance education, revealing any deficiencies that may exist, and making recommendations for situations that will enable distance education to be more effective.

\section{METHOD}

\section{Research Model}

In this research, a case study, one of the qualitative research methods, was used. In a case study, the aim is to analyse one or more cases holistically (Yıldırım \& Şimşek, 2013) and to investigate one or more carefully defined schools, individuals, situations or experiences characterized by time and space (McMillan, 2012). In this context, the aim of this study is to reveal students' experiences related to distance education conducted during the pandemic, from the perspectives of their parents. 


\section{Study Group}

The study group of this research consists of parents $(n=148)$ of students at different elementary schools in Turkey, who were accessible via the children's classroom teachers. The convenience sampling method was used in this study. Personal data related to the study group are given in Table 1 .

Table 1.

Personal data of parents participating in study

\begin{tabular}{|c|c|c|c|}
\hline Variables & & $\mathrm{f}$ & $\%$ \\
\hline \multirow[t]{2}{*}{ Gender } & Female & 124 & 83.8 \\
\hline & Male & 24 & 16.2 \\
\hline \multirow[t]{5}{*}{ Age } & $20-29$ & 19 & 12.8 \\
\hline & $30-39$ & 90 & 60.8 \\
\hline & $40-49$ & 34 & 23.0 \\
\hline & $50-59$ & 4 & 2.7 \\
\hline & $60+$ & 1 & 0.7 \\
\hline \multirow[t]{6}{*}{ Education level } & Primary school & 32 & 21.6 \\
\hline & Secondary school & 23 & 15.5 \\
\hline & High school & 48 & 32.4 \\
\hline & Bachelor's & 41 & 27.7 \\
\hline & Master's & 4 & 2.7 \\
\hline & Doctoral & 0 & 0 \\
\hline
\end{tabular}




\begin{tabular}{llcc}
\hline $\begin{array}{l}\text { Grade level of parents' children } \\
\text { benefiting from distance education }\end{array}$ & $\begin{array}{l}\text { Primary school } \\
\text { (grades 1-4) }\end{array}$ & 148 & 100 \\
& $\begin{array}{l}\text { Secondary school } \\
\text { (grades 5-8) }\end{array}$ & 34 & 23 \\
& High school & & \\
& (grades 9-12) & 26 & 17.6 \\
& Yes & 12 & 8.1 \\
$\begin{array}{l}\text { Number of parents who had previously } \\
\text { received distance education }\end{array}$ & No & 136 & 91.9 \\
& Yes & 2 & 1.4 \\
\hline $\begin{array}{l}\text { Number of children who had previously } \\
\text { received distance education }\end{array}$ & No & 146 & 98.6 \\
\hline
\end{tabular}

Examination of Table 1 reveals that $83.8 \%$ of parents were female (124 parents), $60.8 \%$ of them were aged 30-39 (90 parents), 32.4\% of them were high school graduates (48 parents), and $91.9 \%$ of them (136 parents) and $98.6 \%$ of their children (146 students) had not previously received distance education.

\section{Data Collection Tool}

In this study, a semi-structured interview form entitled Parents' Views Related to the Distance Learning Process, which was developed by the researchers and finalized by obtaining expert opinions, was used. While the interview form was being prepared by the researchers, draft questions were created by examining the literature related to distance education. These questions were evaluated together with three specialists in the field. This form contains 18 questions aimed at parents who had the opportunity to closely monitor their children's experiences in the distance education process. Some of the questions in this form are as follows: "Assess your child's reactions while monitoring his/her distance education lessons." "How do you give your child educational support during the distance learning process?" "In your opinion, what are the positive/negative aspects of distance education with regard to the student and parent?"

\section{Data Collection}

The data of this study were gathered in the 2019-2020 academic year, during the pandemic period when instruction was carried out with distance education via EBA. The semi-structured interview form was sent via Google Forms to parents who were willing 
to participate in the study by way of their children's classroom teachers. The data were collected from the study group following 7 weeks of EBA experience lasting from 23.03.2020 until 11.05.2020. The ethics committee permission for this study was obtained from the Social and Humanities Ethics Committee of the Rectorate of Kafkas University, dated 22/05/2020 and numbered 05.

\section{Data Analysis}

The parents' answers given to the open-ended questions and to questions asking for demographic data, such as their gender, age, and the grade level attended by their children, in the semi-structured interview form, were obtained. The data were analysed with the content analysis method. Codes and categories were determined by the researchers conducting the study. Some of the categories specified are as follows: "access to EBA", "support provided by the children's own teacher during the distance education process", "support provided by parents' to their own children during the distance education process", "advantages of the distance education process for the student", "advantages of the distance education process for parents", "disadvantages of the distance education process for the student", and "disadvantages of the distance education process for parents". According to Miles and Huberman's (1994) formula (Number of Agreements / [Number of Agreements + Number of Disagreements]), an inter-rater reliability value of 0.84 was calculated.

\section{FINDINGS}

According to the views of the parents, it was determined that $83.1 \%$ of children gained access to EBA from television (123 parents), 48.5\% obtained access by mobile phone (72 parents), $25.7 \%$ accessed it via computer (38 parents), and $16.2 \%$ gained access via tablet computer (24 parents). In this study, it was seen that children mostly obtained access to distance education via television and phone. Regarding whether their children had problems with accessing EBA, 54\% of parents said that they did not (80 parents), while $46 \%$ said that they did (68 parents).

Codes for the 68 parents who stated that their children had problems with accessing EBA are given in Table 2 . 
Table 2.

Views of parents (P) related to problems experienced with access to EBA

Category 1: Access to EBA

Codes $\quad$ f $\quad \% \quad$ Participants

Failure to enter EBA/connection 2940.9 P8, P10, P11, P15, P18, P21, P22, P23, problem P34, P35, P36, P42, P47, P56, P66, P87, P90, P94, P103, P106, P111, P114, P117, P122, P127, P131, P136, P137, P140

System problem

Lack of internet

Failure to enter live lesson

Parent's lack of technological knowledge

Fewer electronic devices than number of children at home

Mobile application problem

Problem with accessing materials

Time intervals

No reason for problem experienced was specified

Total number of codes: 10
1521.2 P13, P15, P25, P26, P48, P60, P93, P95, P105, P113, P114, P134, P135, P138, P144

$7 \quad 9.9 \quad$ P1, P16, P41, P52, P92, P110, P145

$5 \quad 7.0 \quad \mathrm{P} 11, \mathrm{P} 21, \mathrm{P} 25, \mathrm{P} 27, \mathrm{P} 83$

$4 \quad 5.6 \quad$ P99, P101, P118, P147

$2 \quad 2.8 \quad \mathrm{P} 16, \mathrm{P} 55$

$2 \quad 2.8 \quad$ P3, P88

$2 \quad 2.8 \quad \mathrm{P} 103, \mathrm{P} 140$

$2 \quad 2.8 \quad \mathrm{P} 12, \mathrm{P} 59$

$2 \quad 2.8 \quad$ P78, P85

$\begin{array}{lll}71 & 100 \quad 68\end{array}$ 
Table 2 shows 10 codes in the category of access to EBA. Some of the codes in this category are "failure to enter EBA/connection problem", "system problem", "lack of internet", and "failure to enter live lesson". Sample quotations related to the codes are:

"Sometimes we cannot open the website, and sometimes we cannot enter the lesson" (V21). "I do not have any problem related to the internet, but because we only have a single electronic device, this is not enough for our 4 children" (V55). "A problem appears with the connection to EBA" (V56).

It was stated by $51.3 \%$ (76 parents) that their children kept up with the lessons prepared according to their grade level from EBA every day, by $19.6 \%$ (29 parents) that their children followed the lessons 3-4 times a week, by 17.6\% (26 parents) that their children followed the classes from time to time, and by $8.1 \%$ (12 parents) that their children kept up with the lessons 1-2 times a week, while 3.4\% of parents (5 parents) stated that their children did not follow the lessons at all. That is, according to the views of the parents, over half of the children kept up with the lessons every day.

When asked how their children preferred to receive distance education, $72.3 \%$ of parents (107 parents) replied, "with live broadcasts by my child's own teachers", 52.7\% (107 parents) stated, "with videos recorded by my child's own teachers", 22.3\% (33 parents) replied, "with live broadcasts by teachers designated by MEB", and 10.1\% (15 parents) stated, "with videos recorded by teachers designated by MEB". In this study, it was seen that most parents reported that their children preferred instruction to be given via live broadcasts or videos recorded by their own teachers.

When parents were asked about their children's willingness to follow the lessons, 59.5\% (88 parents) replied that their children were "moderately willing", 23\% (34 parents) stated that their children were "very willing", 12.8\% (19 parents) said that their children were "slightly willing", while 4.7\% (7 parents) reported that their children were "not willing at all". Accordingly, it can be concluded that most children's willingness to follow the lessons was at a moderate level.

Codes related to parents' assessments of the reactions that their children gave to distance education lessons are given in Table 3. 
Table 3.

Parents' assessments of their children's reactions to distance education lessons

Category 2: Parents' assessments of reactions shown by their children while watching distance education lessons

Codes $\quad$ f $\% \quad$ Participants

\begin{tabular}{ll}
\hline Student is interested/willing $34 \quad 22.0 \quad$ & P6, P17, P20, P34, P38, P41, P56, P57, \\
& P62, P66, P67, P68, P69, P71, P81, \\
& P85, P86, P87, P89, P93, P94, P98, \\
& P100, P102, P104, P106, P111, P116, \\
& P120, P124, P129, P130, P133, P144
\end{tabular}

Student participates/answers $24 \quad 15.5 \quad$ P2, P4, P6, P8, P16, P32, P37, P39, questions P42, P45, P47, P50, P61, P74, P76, P78, P90, P95, P99, P109, P110, P119, P125, P139

Student is changeable

Student listens/watches attentively

Student is

uninterested/unwilling

Student cannot concentrate

Student gets bored

Student does not take it seriously
$21 \quad 13.5$ P11, P12, P14, P15, P22, P24, P25, P33, P53, P60, P72, P84, P92, P97, P112, P114, P122, P141, P142, P146, P148

2012.9 P3, P5, P8, P21, P31, P47, P50, P61, P65, P70, P73, P76, P82, P91, P107, P125, P128, P135, P145, P147

$19 \quad 12.3$ P1, P9, P10, P13, P27, P29, P35, P58, P63, P64, P77, P80, P101, P108, P113, P115, P121, P137, P143

159.7 P36, P43, P44, P49, P51, P59, P96, P103, P117, P123, P126, P127, P134, P136, P140

$5 \quad 3.2 \quad \mathrm{P} 40, \mathrm{P} 54, \mathrm{P} 88, \mathrm{P} 105, \mathrm{P} 132$

$3 \quad 1.9 \quad \mathrm{P} 48, \mathrm{P} 52, \mathrm{P} 55$ 
Student is a passive listener

Student feels alienated by distance learning/misses own teacher

Student was interested at first but interest decreased later

No response given

Total number of codes: 12
$31.9 \quad$ P23, P30, P83

$2 \quad 1.3 \quad$ P18, P19

$2 \quad 1.3 \quad$ P7, P131

$7 \quad 4.5 \quad$ P26, P28, P46, P75, P79, P118, P138

$155100 \quad 148$

Examination of Table 3 reveals 12 codes in the category of parents' assessments of reactions shown by their children while watching distance education lessons. Some of the codes in this category are: "student is interested/willing", "student participates/answers questions", "student is changeable", "student listens/watches attentively", "student is uninterested/unwilling", and "student cannot concentrate". Sample quotations related to the codes are:

"He is not very willing because it is not an environment he is used to. He watches as if he were watching a film. He gets bored, and it doesn't interest him much" (V19). "She listens attentively to the lessons and answers the questions she is asked willingly" (V76). "He sometimes listens to the lesson very willingly, but at other times he can be unwilling" (V148).

When parents were asked if they followed the distance education lessons together with their children, $79.7 \%$ (118 parents) replied that they did, while $20.3 \%$ (30 parents) replied that they did not. Accordingly, it was seen that the great majority of parents followed the lessons together with their children.

When asked whether their children's own teacher provided support in the distance education process, $88.5 \%$ (131 parents) replied that he/she did, while $11.5 \%$ (17 parents) replied that he/she did not. According to the opinions of the parents, it can be said that almost all classroom teachers supported their students during the pandemic.

Codes for parents' views related to support provided by children's own teacher are given in Table 4. 
Table 4.

Parents' views related to support for children provided by their own teacher

Category 3: Support provided by children's own teacher

$\begin{array}{llll}\text { Codes } & \text { f } & \% & \text { Participants }\end{array}$

Homework

Monitoring the child by

communicating with his/her

parents

78

37.3

P2, P4, P5, P6, P7, P8, P9, P11, P12,

P13, P14, P15, P16, P17, P18, P19, P22, P24, P26, P27, P28, P34, P39, $\mathrm{P} 42, \mathrm{P} 44, \mathrm{P} 45, \mathrm{P} 47, \mathrm{P} 52, \mathrm{P} 56, \mathrm{P} 57$, P59, P60, P66, P75, P78, P84, P87, P88, P89, P90, P91, P92, P93, P94, P95, P96, P97, P100, P102, P103, P104, P106, P108, P109, P110, P112, P113, P116, P117, P119, P120, P121, P123, P126, P127, P128, P130, P131, P132, P133, P134, P138, P140, P141, P142, P144, P147, P148

3516.7 P2, P3, P11, P13, P14, P15, P19, P21, P25, P27, P33, P36, P37, P55, P56, P64, P68, P73, P76, P78, P81, P82, P90, P106, P114, P122, P125, P126, P127, P130, P134, P135, P138, P141, P146

Sending lesson videos, lesson 26 12.5 notes, PDF files, and sound/video recordings

2, P7, P8, P10, P23, P32, P33, P47, P48, P50, P56, P58, P59, P89, P91, P98, P101, P103, P108, P109, P117, P123, P134, P138, P146, P147

Preparing activities

115.3 P7, P19, P26, P34, P90, P93, P95, P124, P127, P131, P138,

Reading books

104.8 P33, P51, P97, P102, P103, P107, P108, P112, P117, P144,

Live broadcasts

$9 \quad 4.3$ P1, P12, P41, P60, P66, P105, P127, P128, P143 


\begin{tabular}{|c|c|c|c|}
\hline $\begin{array}{l}\text { Giving support and guidance if } \\
\text { required }\end{array}$ & 9 & 4.3 & $\begin{array}{l}\text { P20, P35, P38, P43, P70, P83, P136, } \\
\text { P137, P145 }\end{array}$ \\
\hline Motivation & 6 & 2.9 & P40, P51, P99, P118, P131, P146 \\
\hline No response given & 8 & 3.8 & $\begin{array}{l}\text { P49, P62, P74, P85, P111, P115, P129, } \\
\text { P139 }\end{array}$ \\
\hline Failure to provide support & 17 & 8.1 & $\begin{array}{l}\text { P29, P30, P31, P46, P53, P54, P61, } \\
\text { P63, P65, P67, P69, P71, P72, P77, } \\
\text { P79, P80, P86 }\end{array}$ \\
\hline Total number of codes: 10 & 209 & 100 & 148 \\
\hline
\end{tabular}

Examination of Table 4 shows that there are 10 codes in the category of support for children provided by children's own teacher. Some of the codes in this category are: "homework", "monitoring the child by communicating with his/her parents", "sending lesson videos, lesson notes, PDF files, and sound/video recordings", and "preparing activities". Sample quotations related to the codes are:

"She is very supportive, she has them do activities, she is very interested, and she goes the extra mile" (V124). "Our teacher does live lessons, checks homework, gives extra homework, and gives the test solutions" (V128). "Our teacher has not lost contact with the students at all; he constantly takes an interest, and provides support in many ways such as sound recordings, video recordings, PDF files, test exams, and activities on important days" (V138).

Codes for parents' views related to the support they themselves gave to their children in the distance education process are given in Table 5. 
Tablo 5.

Parents' views related to support they themselves gave to their children in distance education process

Category 4: Support provided by parents themselves for their children in the distance education process

$\begin{array}{llll}\text { Codes } & \text { f } & \% & \text { Participants }\end{array}$

\begin{tabular}{ll}
\hline $\begin{array}{l}\text { Assistance/encouragement while } 58 \quad 31.9 \\
\text { doing lessons or homework }\end{array}$ & P7, P8, P9, P11, P13, P15, P20, P22, \\
& P24, P25, P27, P28, P29, P30, P33, \\
& P37, P38, P39, P40, P45, P49, P51, \\
& P52, P55, P56, P57, P58, P60, P64, \\
& P70, P78, P79, P80, P88, P90, P91, \\
& P92, P93, P95, P96, P99, P100, \\
& P102, P103, P107, P108, P110, \\
& P112, P113, P117, P122, P127, \\
& P130, P131, P137, P138, P144, \\
& P145
\end{tabular}

Assistance in subjects that are not $24 \quad 13.2 \quad$ P2, P3, P5, P6, P12, P13, P33, P41, understood/correcting deficiencies P47, P54, P60, P61, P76, P89, P98, P99, P103, P108, P112, P122, P128, P142, P145, P146

Support for book reading $19 \quad 10.5 \quad \mathrm{P} 4, \mathrm{P} 8, \mathrm{P} 10, \mathrm{P} 15, \mathrm{P} 18, \mathrm{P} 19, \mathrm{P} 22$, P33, P35, P44, P52, P53, P59, P65, P74, P117, P131, P139, P144

Watching lesson videos other $14 \quad 7.7 \quad \mathrm{P} 13, \mathrm{P} 17, \mathrm{P} 29, \mathrm{P} 48, \mathrm{P} 63, \mathrm{P} 68, \mathrm{P} 71$, than EBA together P82, P94, P101, P106, P135, P141, $\mathrm{P} 147$

Making them do tests/solve $13 \quad 7.2$ P1, P19, P21, P31, P42, P65, P66, problems P76, P90, P123, P134, P139, P148

Ensuring planned study as in the 9 4.9 P14, P16, P43, P54, P67, P72, P73, school environment P83, P119 


\begin{tabular}{|c|c|c|c|}
\hline $\begin{array}{l}\text { Feeling inadequate/unable to } \\
\text { provide support }\end{array}$ & 9 & 4.9 & $\begin{array}{l}\text { P23, P62, P77, P97, P115, P116, } \\
\text { P118, P120, P126 }\end{array}$ \\
\hline $\begin{array}{l}\text { Education with activities and } \\
\text { games }\end{array}$ & 8 & 4.4 & $\begin{array}{l}\text { P10, P17, P25, P44, P78, P91, P93, } \\
\text { P143 }\end{array}$ \\
\hline Giving lessons & 7 & 3.8 & $\begin{array}{l}\text { P84, P104, P109, P114, P133, } \\
\text { P134, P140 }\end{array}$ \\
\hline Buying source books & 7 & 3.8 & $\begin{array}{l}\text { P46, P50, P56, P87, P111, P121, } \\
\text { P136 }\end{array}$ \\
\hline No response given & 14 & 7.7 & $\begin{array}{l}\text { P26, P32, P34, P36, P69, P75, P81, } \\
\text { P85, P86, P105, P124, P125, P129, } \\
\text { P132 }\end{array}$ \\
\hline Total number of codes: 11 & 182 & 100 & 148 \\
\hline
\end{tabular}

When Table 5 is examined, 11 codes in the category of support provided by parents themselves for their children in the distance education process can be seen. Some of the codes in this category are: "assistance/encouragement while doing lessons or homework", "assistance in subjects that are not understood/correcting deficiencies", "watching lesson videos other than EBA together", and "feeling inadequate/unable to provide support". Sample quotations related to the codes are:

"I constantly monitor him, and we listen to the lessons together. I warn him in places where he needs to pay attention. In areas that he does not know about, I learn together with my son, since I also listen to the lesson, and I give explanations in places where he does not understand" (V13). "I buy source books, I regularly follow EBA, and we keep to the lesson schedule just like during normal school times" (V14). "We offer assistance, albeit not as much as the teacher, but I feel inadequate in this regard" (V115).

When parents were asked for their views on which way education should be provided to their children during the pandemic, $76.4 \%$ (113 parents) stated that they preferred education to be given face-to-face, $19.6 \%$ (29 parents) said they preferred both distance and face-to-face education to be provided, while $4.1 \%$ (6 parents) replied that they preferred distance education to be given. It can be seen that in this study, the great majority of parents preferred education to be given face-to-face.

Codes for parents' views related to the advantages of the distance education process for the student are given in Table 6.

Table 6. Parents' views related to advantages of distance education process for student 
Category 5: Advantages of the distance education process for the student

$\begin{array}{llll}\text { Codes } & \text { f } & \% & \text { Participants }\end{array}$

There is no advantage

Time-space independence

Continuity of education

Increase in time set aside by student for him/herself and his/her family

Importance of use of technology 9 in education

Possibility of repetition

Appreciating the value of school

No response given

Total number of codes: 8
$50 \quad 33.8$ P1, P5, P8, P16, P19, P21, P22, P30, P31, P32, P34, P36, P40, P41, P46, P61, P62, P63, P65, P66, P71, P79, P83, P86, P87, P88, P92, P95, P96, P98, P102, P104, P106, P107, P110, P111, P113, P115, P116, P118, P122, P124, P126, P131, P134, P135, P137, P143, P144, P146

2919.6 P7, P11, P12, P15, P18, P20, P24, P25, P27, P33, P42, P43, P48, P51, P52, P53, P54, P55, P60, P70, P74, P82, P84, P93, P101, P140, P141, P147, P148

$24 \quad 16.2$ P2, P10, P17, P23, P35, P44, P45, P47, P57, P58, P68, P80, P81, P85, P94, P99, P100, P109, P117, P119, P127, P130, P138, P139

$18 \quad 12.2$ P4, P9, P13, P39, P54, P56, P59, P72, P73, P103, P105, P112, P120, P123, P125, P128, P133, 145

6.1 P28, P38, P50, P67, P77, P90, P91, P108, P121

$9 \quad 6.1$ P3, P37, P64, P76, P78, P89, P97, P136, $\mathrm{P} 142$

$2 \quad 1.3 \quad \mathrm{P} 6, \mathrm{P} 14$

$7 \quad 4.7 \quad$ P26, P29, P49, P69, P75, P129, P132

$148 \quad 100 \quad 148$ 
Examination of Table 6 reveals 8 codes in the category of advantages of the distance education process for the student. Some of the codes in this category are: "there is no advantage", "time-space independence", "continuity of education", "increase in time set aside by student for him/herself and his/her family", "importance of use of technology in education", and "possibility of repetition". Sample quotations related to the codes are:

"The advantage of distance education for children is that they can move with ease within the concept of time. E.g., they can watch a repeat of lessons that they could not watch on time" (V15). "They understand that the television and telephone can be useful for education" (V108). "Since the children are accustomed to their teachers, it is difficult to manage this process at home. I do not believe that it offers any advantage for the student" (V146).

Codes for parents' views related to the advantages of the distance education process for themselves are given in Table 7.

Table 7.

Parents' views related to advantages of distance education process for themselves

Category 6: Advantages of the distance education process for parents

$\begin{array}{llll}\text { Codes } & \text { f } & \% & \text { Participants }\end{array}$

There is no advantage

Observing the child's interest in

and competence for the lesson

The child is constantly with you/in sight

I learn-I teach
$23 \quad 15.5$ P4, P15, P22, P25, P27, P33, P36, P37,

$53 \quad 35.8$ P1, P5, P8, P9, P10, P12, P14, P16, P18, P19, P23, P31, P34, P35, P40, P42, P46, P52, P53, P57, P63, P65, P69, P71, P77, P78, P79, P83, P86, P87, P88, P96, P97, P100, P102, P106, P111, P113, P115, P116, P118, P123, P126, P131, P133, P134, P135, P136, P138, P143, P144, P146, P147, P38, P39, P51, P64, P66, P67, P76, P84, P90, P92, P93, P121, P128, P139, P140

15 10.2 P6, P20, P24, P41, P54, P55, P56, P61, P62, P82, P94, P99, P104, P105, P122

11 7.4 P13, P17, P28, P29, P44, P47, P58, P73, P91, P132, P145 


\begin{tabular}{|c|c|c|c|}
\hline The child is healthy and safe & 11 & 7.4 & $\begin{array}{l}\text { P60, P68, P74, P81, P107, P109, P112, } \\
\text { P117, P124, P137, P141 }\end{array}$ \\
\hline $\begin{array}{l}\text { Setting aside more time for the } \\
\text { child as a parent }\end{array}$ & 10 & 6.8 & $\begin{array}{l}\mathrm{P} 26, \mathrm{P} 43, \mathrm{P} 45, \mathrm{P} 59, \mathrm{P} 103, \mathrm{P} 114, \mathrm{P} 120, \\
\mathrm{P} 125, \mathrm{P} 139, \mathrm{P} 148\end{array}$ \\
\hline $\begin{array}{l}\text { Parent's satisfaction that the } \\
\text { child is keeping up with his/her } \\
\text { lessons }\end{array}$ & 8 & 5.4 & $\begin{array}{l}\text { P2, P3, P11, P32, P85, P89, P98, P101, } \\
\text { P130, P142 }\end{array}$ \\
\hline It is economical & 4 & 2.7 & P7, P48, P55, P72 \\
\hline There is no school rush & 4 & 2.7 & P67, P70, P95, P110, P127 \\
\hline $\begin{array}{l}\text { Better understanding of the } \\
\text { difficulties faced by teachers }\end{array}$ & 1 & 0.7 & P108 \\
\hline No response given & 8 & 5.4 & $\begin{array}{l}\text { P21, P30, P49, P50, P75, P80, P119, } \\
\text { P129 }\end{array}$ \\
\hline Total number of codes: 11 & 148 & 100 & 148 \\
\hline
\end{tabular}

When Table 7 is examined, it is seen that there are 11 codes in the category of advantages of the distance education process for parents. Some of the codes in this category are: "There is no advantage", "observing the child's interest in and competence for the lesson", "the child is constantly with you/in sight", "I learn-I teach", and "the child is healthy and safe". Sample quotations related to the codes are:

"I am a graduate of elementary school. At first, while doing homework together, I tried to understand since I did not know the subject, and it took up a lot of my time. Now, we listen to the lessons together and I understand, and because I know the subject, I immediately explain the parts that she doesn't understand and she does it herself, or I again help her with the parts that she cannot do" (V13). "My child is always with me and in sight, and I am happy about this" (V54). "I know that he is healthy and safe" (V141).

Codes for parents' views related to the disadvantages of the distance education process for the student are given in Table 8. 
Table 8.

Parents' views related to disadvantages of distance education process for student

Category 7: Disadvantages of the distance education process for the student

$\begin{array}{llll}\text { Codes } & \text { f } & \% & \text { Participants }\end{array}$

Student is away from his/her

teacher and friends

It is not as productive or

permanent as face-to-face

education

Student is away from

school/undisciplined/feels as if

he/she is on holiday

Student cannot focus or

motivate him/herself

Student cannot interact/ask

questions/receive feedback

Student cannot understand the lessons

There is no disadvantage

Students get bored because they are at home
3018.1 P3, P6, P15, P20, P23, P34, P39, P50, P51, P55, P61, P66, P67, P73, P82, P84, P103, P107, P108, P109, P114, P120, P125, P132, P137, P138, P145, P146, P147, P148

$24 \quad 14.5$ P24, P28, P37, P47, P52, P80, P85, P87, P94, P95, P96, P102, P104, P110, P111, P112, P124, P127, P130, P136, P140, P141, P144, P146

$22 \quad 13.3$ P9, P11, P40, P42, P45, P55, P60, P68, P70, P78, P88, P93, P94, P107, P116, P121, P122, P125, P128, P131, P133, P136

$21 \quad 12.7$ P1, P21, P25, P29, P33, P36, P43, P44, P46, P48, P54, P57, P59, P76, P86, P100, P115, P117, P121, P126, P140

159.0 P19, P26, P27, P31, P38, P53, P64, P66, P68, P72, P74, P92, P123, P126, P142

148.4 P10, P13, P15, P16, P32, P41, P54, P71, P86, P98, P105, P113, P134, P143

12 7.2 P17, P18, P35, P58, P65, P69, P81, P90, P118, P119, P129, P135

3.6 P4, P22, P56, P78, P91, P131 


\begin{tabular}{|c|c|c|c|}
\hline $\begin{array}{l}\text { The duration of the lesson is } \\
\text { short }\end{array}$ & 5 & 3.0 & P2, P7, P66, P89, P99 \\
\hline Students miss school & 5 & 3.0 & P12, P14, P101, P109, P139 \\
\hline No response given & 12 & 7.2 & $\begin{array}{l}\text { P5, P8, P30, P49, P62, P63, P75, P77, } \\
\text { P79, P83, P97, P106 }\end{array}$ \\
\hline Total number of codes: 11 & 166 & 100 & 148 \\
\hline
\end{tabular}

Examination of Table 8 shows that there are 11 codes in the category of disadvantages of the distance education process for the student. Some of the codes in this category are: "student is away from his/her teacher and friends", "it is not as productive or permanent as face-to-face education", "student is away from school/undisciplined/feels as if he/she is on holiday", "student cannot focus or motivate him/herself", and "student cannot interact/ask questions/receive feedback". Sample quotations related to the codes are:

"The fact that students are away from their friends and teachers is a disadvantage for them" (V103). "He/she cannot adequately ask his/her teacher about subjects that he/she does not understand, and cannot completely focus on his/her lessons" (V126). "He/she is deprived of the advantages offered by face-to-face education. It is a big obstacle in terms of socialisation" (V146).

Codes for parents' views related to the disadvantages of the distance education process for themselves are given in Table 9.

Table 9.

Parents' views related to disadvantages of distance education process for themselves

Category 8: Disadvantages of the distance education process for parents

Codes $\quad$ f $\% \quad$ Participants

Belief that the child receives unproductive instruction with distance education
2818.4 P6, P7, P11, P21, P31, P42, P46, P47, P48, P54, P58, P61, P62, P70, P71, P82, P85, P86, P98, P99, P100, P104, P107, P111, P112, P124, P126, P141, 
There is no disadvantage

ncrease in parent's

responsibility

Feeling that the parent is not sufficient for the child educationally

child

Emergence of psychological problems between parent and child

The child gets bored

The child is at home all the time

The parent assumes the role of teacher

No response given

Total number of codes: 10
28

18.4 P15, P16, P17, P18, P25, P26, P28, P32, P35, P38, P39, P63, P64, P65, P68, P69, P74, P76, P81, P89, P90, P91, P110, P118, P125, P129, P135, P139

$26 \quad 17.1$ P9, P12, P13, P14, P19, P27, P34, P36, P49, P53, P56, P57, P72, P77, P78, P83, P96, P101, P108, P122, P132, P133, P134, P136, P140, P146,

$25 \quad 16.5$ P3, P22, P23, P37, P44, P50, P59, P66, P67, P73, P87, P92, P93, P94, P95, P102, P105, P109, P115, P123, P128, P138, P143, P144, P145,

95.9 P1, P4, P29, P60, P84, P103, P121, $\mathrm{P} 131, \mathrm{P} 142$,

85.3 P40, P41, P51, P55, P88, P93, P116, $\mathrm{P} 131$

$7 \quad 4.6 \quad$ P24, P52, P88, P113, P114, P117, P147

$7 \quad 4.6 \quad$ P2, P20, P43, P119, P120, P137, P148

63.9 P10, P33, P45, P51, P127, P130,

$85.3 \quad$ P5, P8, P30, P75, P79, P80, P97, P106

$\begin{array}{lll}152 & 100 \quad 148\end{array}$

Examination of Table 9 reveals 10 codes in the category of disadvantages of the distance education process for parents. Some of the codes in this category are: "belief that the child receives unproductive instruction with distance education", "there is no disadvantage" "increase in parent's responsibility", "feeling that the parent is not sufficient for the child educationally", "the parent cannot motivate the child", and "the parent assumes the role of teacher". Sample quotations related to the codes are: 
"There is no order left at home; all the burden is placed on the parents, as they continually have to deal with the child's lessons" (V19). "The negative aspect for me is that encouraging them to do their lessons and even taking on the things that their teacher normally undertakes with each of them is extremely difficult, and I am in the position of switching from housewifery to teaching" (V33). "The parent already has many responsibilities at home, and a parent who has more than one student and child cannot deal with his/her children's education completely" (V49).

\section{RESULTS, DISCUSSIONS AND SUGGESTIONS}

During the Covid-19 pandemic, face-to-face education has been replaced by distance education. During this process, a great deal of responsibility has been placed on parents with regard to the distance education activities conducted for elementary students via EBA. Parents assume the greatest duty in terms of ensuring school discipline for students who are distanced from the school environment. In this process, it can be said that beyond just the education of their children, parents take on the role of teachers. For this purpose, in this study, the views of parents related to the distance education received by elementary school children were obtained.

According to the views of the parents, in terms of access to EBA, it was determined that besides technical problems such as children's failure to enter EBA, connection problems, system problems and failure to enter live lessons, the parents experienced problems such as lack of technical knowledge and lack of internet connection. When students' problems related to distance education are examined, it is seen that problems such as internet connection (Karakaş \& Doğan, 2017), system problems (Özyürek, Bedge, Yavuz \& Özkan, 2016), inability to enter the system (Çoskunserçe \& İşçitürk, 2019), and students being expelled from the system during lessons (Tüysüz \& Çümen, 2016) were experienced in distance education. In parallel with the results revealed in the literature, in this study, which was carried out in relation to distance education conducted during the pandemic, the results reported by parents of elementary school students regarding access to EBA show similarity. Telli Yamamoto and Altun (2020) stated that students experienced problems related to distance education due to lack of technological knowledge. In this study, too, it was concluded that elementary school students had problems in distance education due to the fact that they could not obtain adequate technological support because of their parents' own lack of technological knowledge.

Parents reported that while following the distance education lessons provided with EBA during the pandemic, their children were generally interested and willing, and that they watched the lessons attentively, though according to some parents, their children were unwilling, could not concentrate, and became bored. Moreover, parents stated that their children felt alienated by distance education and felt the absence of their own teachers. Similarly, previous studies related to lessons conducted with distance education reported students' inability to communicate, receive feedback or focus, their lack of attention, their 
boredom with lessons, and their feeling of alienation towards distance education (Yllmaz \& Güven, 2015; Özgöl, Sarıkaya \& Öztürk, 2017; Atasoy \& Yiğitcan Nayir, 2019). However, it is a fact that during the pandemic, distance education is our prerequisite for continuity in education. Therefore, since a number of innovations are required in order to overcome disadvantages such as these, especially during the pandemic, measures must be taken to improve factors such as interaction, motivation and feedback, which are among the most important concepts of education.

In parallel with the responses given by the parents regarding their children's willingness in lessons delivered via distance education, Tuluk and Akyüz (2019) stated that children did not have sufficient motivation for EBA. This situation is concerned with students' beliefs related to distance education conducted via EBA. Therefore, a state of unwillingness in students is accompanied by a situation in which they will experience deficiency in learning. As stated by İbicioğlu and Antalyalı (2005), lack of motivation in children has a negative effect on student achievement. Although teachers had no obligation to provide support during the pandemic, parents reported that teachers provided support in the form of giving homework, being in constant communication, and sending lesson videos, lesson notes, PDF files, and sound and video recordings. Parents stated that they themselves also provided support during the distance learning process in the form of assistance while doing homework, correcting deficiencies, and watching lesson videos other than EBA together. It is reported in the literature that collaboration between teachers, parents and students will be beneficial in distance education (Çakmak \& Taşkıran, 2017). In conclusion, as support for students during this pandemic period, teachers' and parents' efforts to encourage and motivate them for lessons can prevent loss of motivation in students.

It is known that distance education has advantages such as offering time-space independence (Tüysüz \& Aydın, 2007; Gümüş \& Fırat, 2016; Özgöl, Sarıkaya \& Öztürk, 2017; Cabı, 2018; Paydar \& Doğan, 2019, Sezer \& Korucu, 2019) and the possibility to repeat lessons (Tüysüz \& Çümen, 2016; Çakmak \& Taşkıran, 2017; Özgöl, Sarıkaya \& Öztürk, 2017; Cabı, 2018). In this study, the majority of parents reported that distance education eliminated the concepts of time and space, enabled continuity of education during the pandemic, and made it possible for students to repeat lessons. However, it was also seen that some of the parents considered that distance education did not have any benefits.

In the opinion of parents, the disadvantages of distance education offered to children during the pandemic were that children were away from their teacher and friends, were undisciplined due to being away from school, experienced a lack of motivation, and could not ask questions or receive feedback, and parents considered that distance education could not take the place of face-to-face education in terms of productivity. These disadvantages show consistency with the literature related to problems experienced in the distance education process carried out before the pandemic (Cabl, 2018; Sezer \& Korucu, 2019; Özgül \& Uysal, 2016; Yılmaz \& Güven, 2015, Paydar \& Doğan, 2019; 
İbicioğlu \& Antalyall, 2005; Şahin et al., 2017). These problems mentioned by parents may be due to the lack of interaction in distance education (Özgül \& Uysal, 2016). On the other hand, it was concluded that interactive lesson videos increased students' motivation, and enabled them to learn the subject better and focus their attention more on the learning environment (Koçdar, Karadeniz, Bozkurt \& Büyük, 2017). Distance education can be made more effective by considering students' prior knowledge, consolidating lessons with examples, giving feedback and providing an interaction environment (Yalçın İncik, Topçu \& Yağlığlu, 2018). Therefore, it is important for distance education to be conducted synchronously rather than asynchronously, and to give priority to the interaction factor in distance education.

During the pandemic period, when children are distanced from the school environment, educational support for children is provided by the majority of parents. However, it was seen that some parents stated that they felt inadequate with regard to supporting their own children. When parents were asked for their views about the disadvantages of distance education for themselves, it was seen that they believed that their children received unproductive instruction with distance education, that their responsibilities increased, that they could not be productive in terms of supporting their children, and even that psychological problems occurred between parents and children during the pandemic. With regard to the Stay at Home process, which was initiated because of the pandemic, disadvantages expressed by parents were that their children became bored due to being at home all the time, and that parents had difficulty in motivating them. The fact that some parents regarded the adoption of the teacher role as a disadvantage is another finding of this study. According to these findings, it can be said that by taking on the role of teachers during the pandemic, parents had difficulty while conducting educational activities with their children.

When parents were asked for their views about the advantages of distance education for themselves, although the majority of them stated that there was no advantage of distance education, some parents stated that they were better able to observe their child's competence, that their child's being beside them and being healthy and safe during this pandemic were advantages, and that as parents, they were able to set aside more time for their child. It can be said that parents stressed that the introduction of distance education for their children instead of continuing with face-to-face education during the pandemic was more important in terms of their children's health. However, it was seen that the great majority of parents (76.4\%) preferred face-to-face instruction for their children's education, and some parents stated that even if distance education was provided, it should be given together with face-to-face education (19.6\%). It was seen that only a small percentage of parents (\%4.1) preferred distance education. Similar to the parents' views in this study, in previous studies it is seen that students generally preferred face-to-face education (Özyürek, Begde, Yavuz \& Özkan, 2016), and that they wished to receive faceto-face instruction, even if only for a few lesson hours per week (Özgöl, Sarıkaya \& Öztürk, 2017). Özturan, Egeli and Darcan (2000) stated that distance education should be given 
with the support of face-to-face education. However, in some studies, when the two methods were compared with regard to retention of knowledge (Balaman, 2018) and achievement (Ünal, 2017), it was seen that distance education was more effective that face-to-face education. The reasons for parents' preferences regarding face-to-face and distance education may be due to lack of knowledge related to which of these environments may be more effective, or lack of familiarity with distance education. Although parents stated that they preferred face-to-face education for their children, the fact that they also expressed that their children were beside them and were healthy and safe during the pandemic is important. It can be said that during the period of the pandemic, distance education is a necessity for children to be healthy and for ensuring continuity in education. Based on the findings of this study, the following recommendations can be made:

- Especially in order to enable interaction, distance education should be carried out synchronously with live broadcasts by children's own teachers.

- Children should be made to feel that distance education is a necessity during the pandemic.

- To eliminate socialization problems, virtual classrooms should be created and the opportunity for children to communicate with their classmates and teachers should be provided.

- Activities for increasing students' motivation should be included in distance education, and they should be given the opportunity to receive feedback and to establish interaction.

- If distance education has to be continued during the 2020-2021 academic year, then in order to ensure the continuity and productivity of education and to overcome situations such as students feeling as if they are in a holiday environment, distance education should be continued as a compulsory educational process.

- For distance education to be conducted successfully, priority should be given to collaboration between the teacher, student and parents. In the name of assisting with children's education during the pandemic, classroom teachers should provide support to all parents, especially to those who feel inadequate.

\section{References}

Arslan, F., \& Korkmaz, Ö (2019). İlahiyat lisans tamamlama uzaktan eğitim öğrencilerinin etkileşim kaygıları ve uzaktan eğitime dönük tutumları [Theology distance bachelor's degree completion program students' interaction anxiety and attitudes towards distance education]. Ahmet Keleşoğlu Eğitim Fakültesi Dergisi, 1(1), 12-25.

Atasoy, M., \& Yiğitcan Nayir, Ö. (2019). Eğitim bilișim ağı (EBA) video modüllerinin matematik dersinde kullanımına ilişkin öğrenci görüşleri [Students' opinions regarding the use of educational and 
Information Network video modules in math courses]. Uluslararası Bilim ve Eğitim Dergisi 2(1), 2437.

Balaman, F. (2018). Web tabanlı uzaktan eğitim ile geleneksel eğitimin internet programcllı̆̆ 2 dersi kapsamında karşılaştırılması [The comparison of web-based distance education and traditional education in internet programming 2 class]. Itobiad: Journal of the Human \& Social Science Researches, 7(2).1173-1200

Barış, M. F. (2015). Üniversite öğrencilerinin uzaktan öğretime yönelik tutumlarının incelenmesi: Namık Kemal Üniversitesi örneği [Analyzing the university students' attitudes towards distance education: Namık Kemal University case study]. Sakarya University Journal of Education, 5(2), 36-46.

Bilgiç, H. G., \& Tüzün, H. (2015). Yükseköğretim kurumları web tabanlı uzaktan eğitim programlarında yaşanan sorunlar. Açıöğretim Uygulamaları ve Araştırmaları Dergisi, 1(3), 26-50.

Cabı, E. (2018). Uzaktan eğitim ile bilgisayar okuryazarlığı öğretimi: Eğitmen deneyimleri [Teaching computer literacy via distance education: Experiences of the instructors]. Başkent University Journal of Education, 5(1), 61-68.

Coşkunserçe, O., \& İşçitürk, G. B. (2019). Eğitim bilişim ağı (EBA) platformu hakkında öğrencilerin farkındalığının artırılmasına yönelik bir durum çalışması [A case study on increasing students' awareness about the educational information network (EBA) platform]. Eğitimde Nitel Araştırmalar Dergisi, 7(1), 260-276.

Çakmak, Z., \& Taşkıran, C. (2017). Sosyal bilgiler öğretmenlerinin perspektifinden eğitim bilişim ağı (EBA) platformu [Views of social studies teachers on education information network (EBA) platform]. Uluslararası Türk Eğitim Bilimleri Dergisi, 2017(9), 284-295.

Dinçer, S. (2006). Bilgisayar destekli eğitim ve uzaktan eğitime genel bir bakış. Akademik Biliş̧im Konferansı, 9-11 Şubat, Pamukkale Üniversitesi, Denizli.

Eren, A., \& Kaya, M. D. (2017). Üniversite öğrencilerinin uzaktan eğitim sistemine bakış açılarının teknoloji kabul modeli ile incelenmesi [Investigation of university students' perspectives for the distance education systems by technology acceptance model]. Yüzüncü Yıl Üniversitesi Sosyal Bilimler Enstitüsü Dergisi, 1(35).

Ergün, E., \& Kurnaz, F. B. (2017). Çevrimiçi öğrenme ortamlarında sınıf topluluğu hissi ve öğrenci bağlılığı arasındaki ilişki [The relationship between student engagement and sense of community in online learning environments]. Kastamonu Ĕgitim Dergisi, 25(4), 1515-1532.

Gül, İ., \& Arabacı, İ. B. (2018). Uzaktan eğitimle öğrenim gören eğitim yönetimi yüksek lisans öğrencilerinin programa ilişkin görüşleri [Opinions regarding the program of graduate students in educational administration in distance education]. Sosyal Bilimler Araştırmaları Dergisi, 8(1) 79-88.

Gülbahar, Y., \& Karataş, E. (2016). Uzaktan öğretimi uzaktan eğitim yöntemi ile öğrenmek: “E-eğitmen sertifika programı" [Learning distance teaching via distance learning: "E-instructor certificate program"]. Kastamonu Eğitim Dergisi, 24(4), 1867-1880.

Gümüș, M. \& Firat, M. (2016). Açık ve uzaktan öğrenmenin tercih edilme nedenlerinin belirlenmesi. Açıöğretim Uygulamaları ve Araştırmaları Dergisi, AUAd, 2(4), 158-168.

İbicioğlu, H., \& Antalyalı, Ö. L. (2005). Uzaktan eğitimin başarısında imkân algı motivasyon ve etkileşim faktörlerinin etkileri: karşılaștırmalı bir uygulama. Çukurova Üniversitesi Sosyal Bilimler Enstitüsü Dergisi, 14(2), 325-338.

Karaçorlu, A. T., \& Atıcı, B. (2019) EBA platformundaki kavram haritaları ve infografiklerin kullanımına dair öğretmen ve öğrenci görüşleri [Opinions of teacher and student about use of concept maps and infographics in the EBA platform]. Gazi Eğitim Bilimleri Dergisi, 5, 77-96. 
Karakaş, H., \& Doğan, A. (2017). Sınıf öğretmenlerinin sınıfta kullandıkları bilgi iletişim teknolojilerine yönelik olumsuz tutumları ve yaşadıkları sorunlar [Primary school teachers' negative attitudes towards information and communication technology (ICT) and their problems]. Hitit Üniversitesi Sosyal Bilimler Enstitüsü Dergisi, 10(1), 629-654.

Kaysi, F., \& Aydemir, E. (2017). Uzaktan eğitim süreçlerindeki etkileşim boyutlarının değerlendirilmesi [Assessment of interaction dimensions in distance education processes]. Sosyal Bilimler Dergisi, 4 (11), 778-790.

Koçdar, S., Karadeniz, A., Bozkurt, A., \& Büyük, K. (2017). Açık ve uzaktan öğrenmede sorularla zenginleştirilmiş etkileşimli video kullanımı [Use of question embedded interactive videos in open and distance learning]. Eskişehir Osmangazi Üniversitesi Sosyal Bilimler Dergisi 18(2), 93-113.

McMillan, J. H. (2012). Educational Research Fundamentals for the Consumer (6th Ed.) Boston: Pearson.

Miles, M. B., \& Huberman, A. M. (1994). An Expanded Sourcebook Qualitative Data Analysis (2nd Ed.). London: Sage Publications.

Özgöl, M., Sarıkaya, İ., \& Öztürk, M. (2017). Örgün eğitimde uzaktan eğitim uygulamalarına ilişkin öğrenci ve öğretim elemanı değerlendirmeleri [Students' and teaching staff's assessments regarding distance education applications in formal education]. Yükseköğretim ve Bilim Dergisi/Journal of Higher Education and Science 7(2), 294-304.

Özgül, E., \& Uysal, Ö. (2016). Uzaktan yaz okuluna yönelik öğrenci görüşleri. Açıköğretim Uygulamaları ve Araştırmaları Dergisi, 2(3), 130-150.

Özturan, M., Egeli, B., \& Darcan, O. (2000). Türk üniversitelerinde bilgisayar ağlarının uzaktan eğitim aracı olarak kullanılmasına ilişkin bir araştırma. Hacettepe Üniversitesi Eğitim Fakültesi Dergisi, 18(18), 108-113.

Özyürek, A., Begde, Z., Yavuz, N. F., \& Özkan, I. (2016). Uzaktan eğitim uygulamasının öğrenci bakış açısına göre değerlendirilmesi [Evaluation of distance education applications from students' perspective]. Karabük Üniversitesi Sosyal Bilimler Enstitüsü Dergisi, 6(2), 592-605.

Paydar, S., \& Doğan, A. (2019). Öğretmen adaylarının açlk ve uzaktan öğrenme ortamlarına yönelik görüşleri [Teacher candidates' views on open and distance learning environments]. Ë̆itim ve Teknoloji, 1(2), 154-162.

Saklan, H., \& Ünal, C. (2019). Dijital eğitim platformları arasında EBA'nın yeri ile ilgili fen bilimleri öğretmenlerinin görüşleri [Opinions of science teachers on the status of EBA among digital education platforms]. Ondokuz Mayıs Üniversitesi Ĕgitim Fakültesi Dergisi, 38(1), 19-34.

Savaş, A. C., \& Hamamcı, Z. (2010). Okullarda rehberlik hizmetlerinin internet üzerinden yürütülmesine ilişkin veli, öğrenci ve psikolojik danışmanların görüşlerinin incelenmesi [The study on the opinions of parents, students and school counselors concerning the use of internet for counseling and guidance services]. Pamukkale Üniversitesi Eğitim Fakültesi Dergisi, 27(27), 147-158.

Sezer, C., \& Korucu, A. T. (2019). Bilişim teknolojileri ve yazılım dersinde öğrenme yönetim sistemi kullanımının öğrenci akademik başarısına etkisi [The effect of students academic success on the utilization of learning management system in information technologies and software course]. Gazi Eğitim Bilimleri Dergisi, 5, 146-165.

Smaldino, S. E., Lowther, D. L., Mims, C., \& Russell, J. D. (2015) Uzaktan eğitimde öğrenmeyi gerçekleştirme A. Arı (Ed.) \& S. M. ÖZDEMİR, M. CEYLAN, Trans) In Öğretim Teknolojileri ve Öğrenme Araçları [Instructional Technology and Media for Learning] (p. 213-255). Eğitim Yayınevi: Konya (Orijinal yayın tarihi, 2014).

Şahin, L. Y., Karadă̆, N., Bozkurt, A., Doğan, E., Kılınç, H., Uğur, S., Gümüş, S., Öztürk, A. \& Güler, C. (2017). Uzaktan eğitimde oyunlaştırma kullanımı: Oyunlaştııılmış web tabanlı bir alıştırma uygulaması [The 
use of gamification in distance education: A web-based gamified quiz].Turkish Online Journal of Qualitative Inquiry (TOJQI) 8 (4), 372-395.

Şentürk, H. (2020). Milli eğitimde DYK kurslarının uzaktan eğitim yoluyla yürütülmesine yönelik incelenmesi [Examination of DYK courses in national education for distance education]. Anadolu Üniversitesi Eğitim Fakültesi Dergisi (AUJEF), 4(1), 50-66.

Tanrıkulu, F. (2017). EBA'nın Türkçe dersi öğrenme alanlarını karşılama yeterliliğine yönelik öğretmen görüşleri [Teacher opinions on EBA content's satisfying turkish language course learning areas outcomes]. Ana Dili Eğitimi Dergisi, 5(3), 395-416.

Taşlıbeyaz, E., Karaman, S., \& Göktaş, Y. (2014). Öğretmenlerin uzaktan hizmet içi eğitim deneyimlerinin incelenmesi [Examining the experiences of teachers received in service training through distance education]. Ege Eğitim Dergisi, 15(1), 139-160.

Telli Yamamoto, G. \& Altun, D. (2020). Coronavirüs ve çevrimiçi (online) eğitimin önlenemeyen yükselişi [The coronavirus and the rising of online education]. Üniversite Araştırmaları Dergisi, 3(1), 25-34.

Tuluk, G., \& Akyüz, H. İ. (2019) Öğretmen ve öğretmen adaylarının EBA içerik incelemesi: 5. sınıf sayılar alt öğrenme alanı doğal sayılar ünitesi [Investıgatıon of EBA contents by teacher and teacher candidates: 5th grade natural numbers unit]. Ușak Üniversitesi Sosyal Bilimler Dergisi, 12(2), 32-47.

Tüysüz, C., \& Aydın, H. (2007). Web tabanlı öğrenmenin ilköğretim okulu düzeyindeki öğrencilerin tutumuna etkisi [Effect of the web based learning on primary school students' attitudes]. Pamukkale Üniversitesi Eğitim Fakültesi Dergisi, 22(22), 73-78.

Tüysüz, C., \& Çümen, V. (2016). EBA ders web sitesine ilişkin ortaokul öğrencilerinin görüşleri [Opinions of secondary school students about EBA course website]. Uş̧ak Üniversitesi Sosyal Bilimler Dergisi, 9(27/3), 278-296.

Ünal, B. B. (2017). Web tabanlı uzaktan eğitimin fen bilimleri konularında öğrenci başarısına etkisi [Effect of web-based distance education on student achievement in science education]. Uluslararası Türk Ĕ̈itim Bilimleri Dergisi, 2017 (9), 481-490.

Yalçın İncik, E., Topçu, Y. G., \& Yağlığlu, A.O. (2018). Uzaktan eğitim programlarında öğrenim gören öğrencilerin bu programlara ilişkin görüşleri (Mersin Üniversitesi Meslek Yüksekokulu Örneği) [Distance education students' views on these programs (Mersin University Vocational School sample)]. 2nd International Congress on Multidisciplinary Studies/II. Uluslararası Multidisipliner Çalsşmalar Kongresi, Adana/Türkiye

Yıldırım, A., \& Şimşek, H. (2013). Sosyal Bilimlerde Nitel Araştırma Yöntemleri. (Genişletilmiş 9. Baskı). Ankara: Seçkin Yayıncllı.

Yılmaz, G. K., \& Güven, B. (2015). Öğretmen adaylarının uzaktan eğitime yönelik algılarının metaforlar yoluyla belirlenmesi [Determining the teacher candidates' perceptions on distance education by metaphors]. Türk Bilgisayar ve Matematik Eğitimi Dergisi, 6(2), 299-322. 
The ethics committee permission for this study was obtained from the Social and Humanities Ethics Committee of the Rectorate of Kafkas University, dated 22/05/2020 and numbered 05 . 


\title{
Covid-19 Pandemi Sürecinde Yürütülen Uzaktan Eğitimle İlgili İlkokul Öğrenci Velilerinin Görüşleri*
}

\section{Nilgün GÜNBAŞ ${ }^{* *}$}

\author{
Meral GÖZÜKÜÇÜK ${ }^{* * *}$
}

\begin{abstract}
Öz. Covid-19 pandemisi nedeniyle, Milli Eğitim Bakanlığı eğitimin yüz yüze yapılmasına ara vermiş ve EBA üzerinden uzaktan eğitim yoluyla eğitim faaliyetlerini sürdürmeye başlamıştır. Pandemi öncesinde ülkemizde yaygın olarak kullanılmayan uzaktan eğitim, pandemi sürecinde bir zorunluluk haline gelmiştir. Bu çalışmanın amacı pandemi sürecinde ilkokul öğrencileri için EBA üzerinden yürütülen uzaktan eğitim faaliyetlerinin veli bakış açısıyla ele alınmasıdır. $\mathrm{Bu}$ araştırmada nitel araştırma yöntemlerinden durum çalışması kullanılmıștır. Araştırmanın çalışma grubunu ilkokul velileri oluşturmaktadır. Velilerden kolay ulaşılabilir örnekleme yöntemiyle (n =148) dijital ortamda oluşturulan görüşme formuyla görüş alınmıştır. Araştırma bulgularına göre veliler; çocuklarının EBA'ya giriş yapamama, canlı derslere girememe ve internet problemlerinin olduğunu belirtmişlerdir. Veliler, bu gibi teknik problemlerin yanı sıra pandemi sürecinde çocukların sürekli evde olmalarından dolayı okul disiplisinden uzaklaştıklarını, derse motive olamadıklarını, ders esnasında dönüt alamadıkları için kalıcı öğrenmenin sağlanmadığını ifade etmişlerdir. Bu olumsuz durumların aksine bazı veliler çocuklarının evde, sağlıklı ve güvenli bir ortamda eğitimlerini sürdürebiliyor olmalarını, konuları tekrar edebilme olanağı bulmalarını, çocuklarının öğrenme süreçlerini takip edebiliyor olmalarını pandemi sürecinde sürdürülen uzaktan eğitimin olumlu yönleri olarak belirtmişlerdir.
\end{abstract}

Anahtar Kelimeler: Covid-19 pandemisi, Uzaktan Eğitim, EBA, İlkokul, Veli

\footnotetext{
* Bu çalışma için etik kurul izni 22/05/2020 tarih ve 05 sayılı Kafkas Üniversitesi Rektörlüğü Sosyal ve Beşeri Bilimler Etik Kurulu Başkanlığı'ndan alınmıştır.

${ }^{* *}$ Orcid ID: https://orcid.org/0000-0003-2578-3083, Dr. Öğr. Üyesi, Kafkas Üniversitesi Matematik Eğitimi Anabilim Dalı, Türkiye, ng2248@tc.columbia.edu

*** https://orcid.org/0000-0002-1620-5073 , Dr. Öğr. Üyesi, Kafkas Üniversitesi Sınıf Eğitimi Anabilim Dalı, Türkiye, meralyaprak@gmail.com
} 


\section{GİRIŞ}

Öğretmen ve öğrencinin okul ortamında fiziksel olarak bulunmasını gerektirmeyen uzaktan eğitim, zaman ve mekân bağımsızlı̆ı sunarak öğretime olanak sağlar. Mektupla öğretim yoluyla başlayan uzaktan eğitim, ses ve video gibi kaynakların kullanılmasıyla farklı bir forma dönüşmüştür (Smaldino, Lowther, Mims ve Russell, 2015). Uzaktan eğitim eş zamanlı (senkronize) veya eş zamansız (asenkronize) yürütülebilir ve öğrenciye anlamadığı konuları tekrar etme olanağı sunabilir (Dinçer, 2006). Ayrıca öğretmenlerin ve öğrencilerin ders içeriklerini paylaşabildikleri ve etkileşim içerisinde bulunabildikleri bir ortam sağlayabilir. Pandemi öncesinde ülkemizde yaygın olarak kullanılmayan uzaktan eğitim, Covid-19 pandemi sürecinde zorunluluk haline gelmiştir.

MEB, Covid-19 pandemi vakalarının Türkiye'de görülmeye başladığı andan itibaren ilk ve orta dereceli okullarda uzaktan eğitime geçmiştir. 16 Mart 2020 tarihinde yüz yüze eğitime ara verilmiş ve 23 Mart 2020 tarihi itibariyle öğrencilerin eğitimden kopmaması adına uzaktan eğitim faaliyetlerine başlanmıştır. Bu amaçla Erişim Bilişim Ağı (EBA) aracılığıyla hem TV hem de internet ortamında 1. sınıftan 12. sınıfa kadar olan bütün öğrencilere uzaktan eğitim olanağı sağlanmıştır. Uzaktan eğitim ilk başladığında asenkron olarak MEB'in belirlediği öğretmenler tarafından yapılmıştır. Daha sonra EBA'da öğrencilerin kendi öğretmenleri tarafından yapılan canlı yayınlarla devam etmiștir. Covid-19 pandemi sürecinde öğrencilerin eğitimden uzaklaşmaması adına uzaktan eğitim faaliyetlerinin başlaması önemli bir husustur. Ancak ilkokul öğrencilerinin çoğunluğu ilk defa uzaktan eğitim deneyimi edinmektedir. Dolayısıyla velilerin çoğunluğu da çocuğunun eğitimini, ilk defa uzaktan eğitimle sürdürmesine şahit olmaktadır. Pandemi sebebiyle uzaktan eğitim yoluyla eğitimine devam eden ilkokul öğrencilerinin eğitimine destek olunması hususunda velilere daha fazla sorumluluk düşmektedir. Bu sebeple Covid-19 pandemi sürecinde ilkokul öğrencilerinin uzaktan eğitim yoluyla aldıkları eğitimle ilgili velilerin görüşleri önemlidir. Bu çalışma, pandemi sürecinde EBA'da yürütülen uzaktan eğitimle ilgili ilkokul öğrenci velilerinin görüşlerini alma, ilkokulda uygulanan uzaktan eğitimin verimliliğini ve varsa mevcut eksikliklerini ortaya koyma anlamında önemlidir.

\section{Uzaktan Eğitim}

Uzaktan eğitim mektupla başlayan günümüz teknolojileriyle daha zengin içerikler sunabilen bir platformdur (Bilgiç ve Tüzün, 2015). Zaman içerisinde e-öğrenme veya dijital öğrenme adını alan uzaktan eğitimin internet üzerinden sunulması akıllara erişim olanağı olmayan bireyleri getirmektedir. Fakat gün geçtikçe daha fazla oranda artan internet kullanıcı sayısının bireylerin uzaktan eğitime adapte olmaları açısından bir sorun teşkil etmeyeceği inancı gelişmiştir (Telli Yamamoto ve Altun, 2020). Uzaktan eğitim daha çok yüz yüze verilen eğitime destek olarak ve bazı üniversitelerin sınırlı sayıdaki programlarında kullanılmaktayken (Şentürk, 2020) yaşanılan salgın nedeniyle tamamen yüz yüze eğitimin yerini almıştır. Bu sebeple uzaktan eğitimin olabildiğince yüz yüze eğitimin sağladığı eğitim olanaklarını (etkileşim, motivasyon, dönüt vb.) sunması açısından gereken tedbirlerin alınması gerekmektedir. 
Akıllı telefonu, tableti, bilgisayarı ve internete erişimi olan öğrencilerin olmayanlara göre uzaktan eğitime karşı tutumlarının daha olumlu olduğu sonucuna ulaşılmıştır (Barış, 2015). Bu sebeple internet erişiminin sorun teşkil etmesi durumuna çözüm olarak MEB, öğrencilere fırsat ve imkân eşitliğini gözeterek EBA'da kullanabilmek üzere ücretsiz internet desteği sağlamış ve canlı yayınlara ağırlık vermiştir.

Uzaktan eğitimin başarı ile yürütülebilmesi için öğretmenlerin, öğrencilerin ve velilerin sorumluluklarını tam olarak yerine getirmeleri gerekmektedir (Eren ve Kaya, 2017). Etkinlikleri ve verilen görevleri zamanında tamamlamak öğrencinin kendi sorumluluğundadır (Gülbahar ve Karataş, 2016). Ancak öğrencilere çevrimiçi öğrenme ortamlarında sunulan etkinliklerin niteliği öğrencilerin ortamla ilgili düşüncelerini etkilemektedir (Ergün ve Kurnaz, 2017). Ayrıca öğretmenler, öğrenciler ve veliler sisteme aşina olsalar bile bu durum uzaktan eğitimin başarılı bir şekilde yürütülebileceği anlamına gelmemektedir.

Öğrencilerin uzaktan eğitim sisteminde sürece aktif bir şekilde katılabilmelerini etkileyen birtakım faktörler bulunmaktadır. Dönüt alabilme, dersin örneklerle pekiştirilmesi, yüz yüze eğitimde olduğu gibi ön bilgilerinin dikkate alınması ve etkileşim ortamının sunulması önemli faktörlerdendir (Yalçın İncik, Topçu ve Yağlığlu, 2018). Kaysi ve Aydemir (2017) uzaktan eğitimle verilen derslerde karşılıklı etkileşimin öğrencilerin derslere olan ilgisini artırdığını ve bu durumun eğitmenleri de olumlu etkilediğini belirtmişlerdir. Savaş ve Hamamcı (2010)'nın çalışmasında velilerin öğretmenlerle iletişim kurmaları, çocuklarının durumunu takip etmeleri ve bilgi edinmeleri gibi sebeplerle teknolojiden yararlanmayı istedikleri görülmektedir.

\section{Erişim Bilişim Ağı (EBA)}

EBA, Türkiye'de ilk ve orta dereceli okullarda ücretsiz çevrimiçi bir eğitim platformudur. EBA özellikle FATİH projesinin teknolojik içerik gereksinimini sağlamak amacıyla kurulan hem sınıf ortamında hem de sınıf dışında öğretmen ve öğrencilerin internetin bulunduğu her yerden yararlanabileceği bir ortamdır (Karaçorlu ve Atıcl, 2019). MEB, EBA'yı yenilemiş e-rehberlik, oyunlaştırma, kitaplar için karekod uygulaması, derslerin video kütüphanesi gibi platformlar eklemiştir. MEB tarafından oluşturulan içeriklere ek olarak EBA, öğretmen ve öğrencilerin oluşturdukları içeriklerle zenginleştirilmektedir. EBA öğrencilerin akranlarıyla grup çalışmaları yapabilmelerine ve iletişimde bulunabilmelerine imkan sağlamaktadır (Saklan ve Ünal, 2019). Tuluk ve Akyüz (2019) çocukların ebeveynleriyle birlikte internetin olduğu her yerde EBA'yı kullanabilmekte olduklarını, öğretmenlerin ise daha sık kullanması gerektiğini, öğrencilerine EBA'yı kullanmayı önerdiklerini fakat gerekli motivasyonu sağlayamadıklarını belirtmişlerdir. Öğrencilerin ve velilerin uzaktan eğitime yönelik inançları, onların EBA'da yürütülen eğitime yönelik motivasyonlarını etkilemektedir.

Uzaktan eğitimde etkileşim oldukça önemli bir faktördür. İbicioğlu ve Antalyalı (2005) konu içeriği çok iyi olsa bile yeterli bir düzeyde etkileşim olmadığında kalıcı öğrenmenin sağlanmadığı, öğrencilerin uzaktan eğitimle ilgili algılarının, bilgisayar kullanma ve motivasyon düzeylerinin uzaktan eğitimdeki başarılarını etkilediği sonucuna 
ulaşmışlardır. Paydar ve Doğan (2019) çalışmasında öğrencilerin \%49.2'sinin uzaktan eğitimin avantajı olduğunu, \%50.8'inin ise dezavantajı olduğunu belirttikleri görülmektedir. Uzaktan eğitim platformu olan EBA'nın kullanılmasında genel olarak uzaktan eğitimin ve spesifik olarak EBA'nın avantaj ve dezavantajlarını bilme bu platformlardan etkili bir şekilde yararlanma adına önemlidir.

\section{Uzaktan Eğitimin Avantajları}

Uzaktan eğitimin en fazla bahsi geçen avantajının zaman ve mekân esnekliği olduğu bildirilmektedir (Tüysüz ve Aydın, 2007; Gümüş ve Fırat, 2016; Özgöl, Sarıkaya ve Öztürk, 2017; Cabı, 2018; Paydar ve Doğan, 2019, Sezer ve Korucu, 2019). Derslerin tekrar izlenebilmesi uzaktan eğitimin bir diğer avantajıdır (Tüysüz ve Çümen, 2016; Çakmak ve Taşkıran, 2017; Özgöl, Sarıkaya ve Öztürk, 2017; Cabı, 2018). MEB’nın kullandığı uzaktan eğitim platformu olan EBA'nın avantajları ise konu tekrarı yapabilme, konuları pekiştirebilme, test çözebilme, eğitici oyunlar oynayabilme ve eğitici videolar izleyebilme olarak belirtilmiştir (Tüysüz ve Çümen, 2016). Çakmak ve Taşkıran (2017) öğretmenöğrenci ve veli arasında iş birliği sağlanırsa EBA'nın daha yararlı olacağı ve öğrencilerin okula gelmeden de EBA'dan yararlanabileceklerini belirtmişlerdir.

Öğretmenlerin EBA gibi eğitim platformlarına aşina olmaları, teknoloji kullanımı konusunda bilgi sahibi olmaları ve EBA gibi platformların üst düzey teknoloji bilgisi gerektirmediği göz önüne alındığında uzaktan eğitim konusundaki tecrübe eksikliklerinin öğretmenler için çok fazla engel teşkil etmeyeceği söylenebilir (Şentürk, 2020). Ayrıca öğrencilerin EBA platformunu düzenli olarak kullanıyor olmaları (Coşkunserçe ve İşçitürk, 2019), EBA'ya yönelik motivasyonlarının artırılması, öğrenmelerinin desteklenmesi, zaman-mekân bağımsızlı̆̆ının sağlanması olumlu bir durum teşkil etmektedir (Sezer ve Korucu, 2019). Pandemi sürecinde öğretmenlerin ve öğrencilerin uzaktan eğitim yoluyla eğitim faaliyetlerini sürdürme durumunda kaldıkları göz önünde bulundurulduğunda, bu sistemin bu süreçte yürütülmesi adına önemli bir engelin bulunmadığı söylenebilir. Özellikle günümüzde kullanılan dijital öğrenci kavramının bir uzantısı olarak öğrencilerin teknolojiyle iç içe olmaları ve dijital kaynaklara erişime yabancı olmamaları onların e-öğrenmeye açık olduklarının bir göstergesidir.

Uzaktan eğitimde devam zorunluluğunun olmaması ve normal şartlar altında fazla sayıda öğrencinin bir araya gelme ihtimalinin olamayacağı durumlarda fiziksel engeli ortadan kaldırabilmesi yine uzaktan eğitimin avantajları arasındadır (Cabı, 2018). İçerik olarak farklı seçenekler sunabilen uzaktan eğitimin öğrencilerin başarılarına olumlu etki ettiği ve gereksinimlerine göre belirlenebildiği için öğrenci merkezli eğitime uygun olduğu söylenebilir (Tüysüz ve Aydın, 2007). Uzaktan eğitimin özellikle etkileşim, motivasyon ve dönüt gibi olanakları sağlayamadığı düşünüldüğünde bu özelliklerin uzaktan eğitimde yürütülen ders içeriklerinde bulunması gerektiği söylenebilir. Nitekim, Koçdar, Karadeniz, Bozkurt ve Büyük (2017) öğrencilerin etkileşimli ders videolarını oldukça memnuniyetle karşıladıklarını, konuyu daha iyi anladıklarını, daha kısa sürede ve kalıcı öğrendiklerini, dikkatlerini daha iyi verebildiklerini ve eğlenerek öğrendiklerini 
belirtmişlerdir. Uzaktan eğitimde bu tür özelliklerin sağlanması uzaktan eğitimin verimliliği açısından önemlidir.

\section{Uzaktan Eğitimin Dezavantajları}

Uzaktan eğitimin işleyişinin yüz yüze eğitimin işleyişinden farklı olmasından kaynaklı olarak sorun yaşanabilmektedir. Yüz yüze eğitime alışık olan, tablet, bilgisayar vb. araçlara sahip olmayan, teknolojik bilgi eksikliği olan veya interneti olmayan öğrenciler uzaktan eğitimde yürütülen dersleri takip etmede zorluk çekmektedirler (Telli Yamamoto ve Altun, 2020). Özellikle internet üzerinden yürütülen uzaktan eğitimde internet bağlantısı (Karakaş ve Doğan, 2017) ve ödevlerin yüklenememesi gibi teknik sorunların yaşandığı bildirilmektedir (Özyürek, Begde, Yavuz ve Özkan, 2016). Canlı derslerle ilgili olarak ses ve görüntü kalitesinin iyi olmamasından dolayı sorun yaşandığı belirtilmektedir (Gül ve Arabacı, 2018). Ayrıca Cabı (2018)'nın yaptığı çalışmada uzaktan eğitim alan öğrencilerin canlı derse katılma durumlarının dersler ilerledikçe azaldığı, yeterli düzeyde açıklayıcı dönüt verilememesinin uzaktan eğitimin dezavantajları arasında olduğu belirtilmiştir.

EBA'da yürütülen uzaktan eğitimle ilgili sisteme giriş yapamama (Coşkunserçe ve İşçitürk, 2019), şifre sorunu, EBA içeriğinde bulunan videoların, ödevlerin çok yavaş açılması ve ders esnasında öğrencilerin sistemden atılması (Tüysüz ve Çümen, 2016) gibi sorunların yaşandığı belirtilmiştir. Öğrencilerin alıștıkları yüz yüze eğitimden farklı bir şekilde eğitim almalarından kaynaklı bir durum olduğu için Atasoy ve Yiğitcan Nayir (2019)'in çalışmasında öğrencilerin EBA'da işlenen derslere odaklanamadıkları, dersleri dikkatli bir şekilde dinleyemedikleri, derslerde not tutamadıkları için kalıcı öğrenme sağlayamadıkları belirtilmiştir. Ayrıca Tanrıkulu (2017)'nun çalışmasında öğretmenlerin EBA'daki derslerin içeriklerini etkili bir şekilde kullanamadıkları belirtilmiştir.

EBA'ya erişim, mobil uygulamaya giriş yapamama gibi teknik sorunların yanı sıra yetersiz dönütler, yeterince sosyalleşememe, iletişim, dikkat dağınıklığı gibi sorunlara da rastlanmaktadır (Sezer ve Korucu, 2019; Özgül ve Uysal, 2016; Yılmaz ve Güven, 2015, Paydar ve Doğan, 2019; İbicioğlu ve Antalyalı, 2005). Uzaktan eğitimle yürütülen derslerde devamsızlık alınmadığı, özellikle uygulama derslerinde uzaktan eğitimin yetersiz kaldığı, öğrencilerin deneyim eksikliği yaşadığı ve etkileşimin fazla olmadığı belirtilmiştir (Özgöl, Sarıkaya ve Öztürk, 2017). Barış (2015) öğrencilerin uzaktan eğitime ilişkin tutumlarının düşük olmasının sebebinin uzaktan eğitime sıcak bakmamalarından kaynaklanıyor olabileceğini belirtmektedir. Nitekim İbicioğlu ve Antalyalı (2005) ilk defa uzaktan eğitim alan öğrencilerin motivasyonlarının düşük olduğunu belirtmektedir.

Bilgiç ve Tüzün (2015) uzaktan eğitimin avantajlarında belirtilen zaman-mekân bağımsızlığını aslında uzaktan eğitimdeki en önemli sorunların kaynağı olarak görmektedirler. Nitekim öğrencilerin, öğretmenlerinden ve akranlarından ayrı olmaları ve onlarla iletişim kuramamaları nedeniyle motivasyon kaybına neden olur (Şahin vd., 2017; Özyürek, Begde, Yavuz ve Özkan, 2016). Özellikle eş zamansız yürütülen uzaktan eğitimde etkileşim konusunda yaşanan sinırlılıklar sorun olarak bildirilmektedir (Taşlıbeyaz, Karaman ve Göktaş, 2014). Bununla birlikte, öğrencilerin uzaktan eğitimde 
etkileşim kaygı düzeylerinin beklenenden yüksek olduğu görülmektedir (Arslan ve Korkmaz, 2019).

Covid-19 pandemisinden dolayı ilkokullarda eğitim faaliyetleri yüz yüze yapılamamıştır. Bu çalışmada Covid-19 pandemi sürecinde EBA aracılığıyla yürütülen uzaktan eğitimle ilgili ilkokul öğrenci velilerinin görüşlerini alınmıştır. Çünkü İlkokul öğrencilerinin uzaktan eğitimle yürütülen faaliyetlerde hem teknik olarak hem de öğrenmeye yardımcı olma anlamında veli desteğine daha çok ihtiyacı vardır. Ayrıca veliler, derslerin uzaktan yürütülmesi sebebiyle çocuklarının aldıkları eğitime şahit oldukları için çocuğunun eğitimi hususunda farkındalık kazanabilir. $\mathrm{Bu}$ araştırmada EBA üzerinden ders kayıtlarıyla ve canlı derslerle yürütülen uzaktan eğitim faaliyetlerinin veli bakış açısıyla olumlu/olumsuz yönlerinin belirlenerek önerilerde bulunulması amaçlanmaktadır. $\mathrm{Bu}$ kapsamda bu çalışmada "Covid-19 pandemi sürecinde ilkokullarda yürütülen uzaktan eğitim faaliyetleri ile ilgili ilkokul öğrencileri velilerinin görüşleri nelerdir?” sorusuna cevap aranmıştır. İlkokul çağındaki çocuk için eğitimde velinin etkisi önemli olduğu için bu çalışmanın sonuçlarına göre uzaktan eğitimle yürütülen faaliyetlerde eğitimin verimliğinini artırma, varsa eksikliklerini ortaya koyma ve uzaktan eğitimde daha verimli olabilecek durumları önerebilme anlamında önemlidir.

\section{YÖNTEM}

\section{Araştırma Modeli}

$\mathrm{Bu}$ araştırmada nitel araştırma yöntemlerinden durum çalışması kullanılmıştır. Durum çalışmasında amaç; bir veya birkaç durumu bütüncül olarak analiz etme (Yıldırım ve Şimşek, 2013) ve dikkatli bir şekilde tanımlanmış zaman ve mekânla karakterize edilmiş olan bir veya daha fazla okul, birey, durum veya deneyimin araştırılmasıdır (McMillan, 2012). Bu bağlamda bu çalışmada pandemi sürecinde yürütülen uzaktan eğitimle ilgili öğrenci deneyimlerinin veli bakış açısıyla ortaya konması hedeflenmiştir.

\section{Çalışma Grubu}

$\mathrm{Bu}$ araştırmadaki çalışma grubu, sınıf öğretmenleri aracılığıyla ulaşılabilen Türkiye'nin farklı illerindeki ilkokul öğrenci velilerinden $(n=148)$ oluşmaktadır. Bu araştırmada kolay ulaşılabilir örneklem yöntemi kullanılmıştır. Çalışma grubuna ait kişisel veriler Tablo 1'de verilmiştir. 
Tablo 1.

Çalışmaya katılan velilerin kişisel bilgileri

\begin{tabular}{|c|c|c|c|}
\hline Değişkenler & & $\mathrm{f}$ & $\%$ \\
\hline \multirow[t]{2}{*}{ Cinsiyet } & Kadın & 124 & 83.8 \\
\hline & Erkek & 24 & 16.2 \\
\hline \multirow[t]{5}{*}{ Yaş } & $20-29$ & 19 & 12.8 \\
\hline & $30-39$ & 90 & 60.8 \\
\hline & $40-49$ & 34 & 23.0 \\
\hline & $50-59$ & 4 & 2.7 \\
\hline & $60+$ & 1 & 0.7 \\
\hline \multirow[t]{6}{*}{ Eğitim seviyesi } & İlkokul & 32 & 21.6 \\
\hline & Ortaokul & 23 & 15.5 \\
\hline & Lise & 48 & 32.4 \\
\hline & Üniversite & 41 & 27.7 \\
\hline & Yüksek Lisans & 4 & 2.7 \\
\hline & Doktora & 0 & 0 \\
\hline \multirow{3}{*}{$\begin{array}{l}\text { Velilerin uzaktan eğitimden faydalanan } \\
\text { çocuklarının sınıf seviyesi }\end{array}$} & İlkokul (1-4. sınıf) & 148 & 100 \\
\hline & Ortaokul (5-8. sınıf) & 34 & 23 \\
\hline & Lise (9-12. sinif) & 26 & 17.6 \\
\hline \multirow{2}{*}{$\begin{array}{l}\text { Velilerin daha önce uzaktan eğitim alma } \\
\text { durumları }\end{array}$} & Evet & 12 & 8.1 \\
\hline & Hayır & 136 & 91.9 \\
\hline
\end{tabular}


Çocukların daha önce uzaktan eğitim Evet

2

1.4

alma durumları

Hayır

146

98.6

Tablo 1 incelendiğinde çalışmaya katılan velilerin \%83.8'inin (124 veli) kadın olduğu, \% 60.8'inin (90 veli) 30-39 yaş aralığında olduğu, \% 32.4'ünün (48 veli) lise mezunu olduğu, \%91.9'unun (136 veli) ve çocukların \%98.6'sının (146 öğrenci) uzaktan eğitim almadığı belirlenmiştir.

\section{Veri Toplama Aracı}

Bu çalışmada araştırmacılar tarafından geliştirilen ve uzman görüşüyle son şeklini alan Uzaktan Eğitim Süreci ile İlgili Velilerin Görüşleri başlıklı yarı yapılandırılmış görüşme formu kullanılmıştır. Araştırmacılar tarafından görüşme formu hazırlanrken uzaktan eğitimle ilgili alanyazın incelenerek taslak sorular oluşturulmuştur. Bu sorular alanda uzman üç kişiyle birlikte değerlendirilmiştir. Bu formda çocuklarının uzaktan eğitim sürecinde yaşadıkları deneyimleri yakından gözlemleme olanağına sahip olan velilere yönelik 16 soru bulunmaktadır. Bu formdaki bazı sorular: “Çocuğunuzun uzaktan eğitim derslerini izlerken tepkilerini değerlendiriniz. Uzaktan eğitim sürecinde siz çocuğunuza eğitimsel açıdan nasıl destek oluyorsunuz? Sizce uzaktan eğitimin öğrenci ve veli açısından olumlu/olumsuz yanları nelerdir?" şeklindedir.

\section{Verilerin Toplanması}

Bu çalışmanın verileri 2019-2020 eğitim-öğretim yılı içerisinde eğitimin EBA üzerinden uzaktan eğitimle sürdürüldüğü pandemi sürecinde toplanmıştır. Yarı yapılandırılmış görüşme formu sınıf öğretmenleri aracılığıyla çalışmaya katılmaya gönüllü olan velilere Google Forms üzerinden gönderilmiştir. Veriler çalışma grubundan 23.03.2020 tarihinden 11.05.2020 tarihine kadar 7 haftalık EBA deneyiminden sonra toplanmıştır. Bu çalışma için etik kurul izni 22/05/2020 tarih ve 05 sayılı Kafkas Üniversitesi Rektörlüğü Sosyal ve Beşeri Bilimler Etik Kurulu Başkanlığı'ndan alınmıştır.

\section{Verilerin Analizi}

Yarı yapılandırılmış görüşme formunda velilerin cinsiyet, çocuklarının devam ettikleri sınıf düzeyi, yaş gibi demografik ve açık uçlu sorulara verdikleri cevaplar alınmıştır. Veriler içerik analizi yöntemiyle analiz edilmiştir. Çalışmayı yürüten araştırmacılar tarafından kodlar ve kategoriler belirlenmiştir. Belirlenen kategorilerden bazıları: "EBA'ya erişim, çocukların kendi öğretmeni tarafindan sağlanan destek, velilerin çocuklarına uzaktan eğitim sürecinde kendileri tarafından sağlanan destek, uzaktan eğitim sürecinin öğrenci açısından avantajları, uzaktan eğitim sürecinin veliler açısından avantajları, uzaktan eğitim sürecinin öğrenci açısından dezavantajları, uzaktan eğitim sürecinin veliler açısından dezavantajları" șeklindedir. Miles ve Huberman (1994) in Görüş Birliği / (Görüş Birliği + Görüş Ayrılığı) formülü ile güvenirlik değeri 0.84 olarak hesaplanmiştır. 


\section{BULGULAR}

Velilerin görüşlerine göre çocukların \%83.1'inin (123 veli) televizyondan, \%48.6'sının (72 veli) telefondan, \%25.7'si (38 veli) bilgisayardan ve \%16.2'sinin (24 veli) tabletten EBA'ya erişim sağladığı sonucuna ulaşılmıştır. Bu çalışmada çocukların en fazla televizyondan ve telefondan uzaktan eğitime erişim sağladıkları görülmüştür. EBA'ya erişim konusunda çocukların sorun yaşayıp yaşamadıklarına ilişkin velilerin \%54'ü (80 veli) hayır \%46’sı (68 veli) evet cevabını vermiştir. EBA'ya erişimde sorun yaşadığını ifade eden 68 veliye ait kodlar Tablo 2'de verilmiştir.

Tablo 2.

Velilerin (V) EBA'ya erişimde sorun yaşama konusunda görüşleri

1.Kategori: EBA'ya Erişim

Kodlar $\quad$ f $\% \quad$ Katılımclar

EBA'ya giriș

yapamama/bağlanma sorunu

Sistem sorunu

İnternetin olmaması

Canlı derse girememe

Velinin teknolojik bilgi

yetersizliği

Evdeki çocuk sayısının çok

elektronik cihazın az olması

Mobil uygulama sorunu

Materyallere erişim problemi

Saat aralıkları

29

40.9

V8, V10, V11, V15, V18, V21, V22, V23, V34, V35, V36, V42, V47, V56, V66, V87, V90, V94, V103, V106, V111, V114, V117, V122, V127, V131, V136, V137, V140

1521.2 V13, V15, V25, V26, V48, V60, V93, V95, V105, V113, V114, V134, V135, V138, V144

$7 \quad 9.9$ V1, V16, V41, V52, V92, V110, V145

$5 \quad 7.0 \quad \mathrm{~V} 11, \mathrm{~V} 21, \mathrm{~V} 25, \mathrm{~V} 27, \mathrm{~V} 83$

$4 \quad 5.6 \quad$ V99, V101, V118, V147

$2 \quad 2.8 \quad \mathrm{~V} 16, \mathrm{~V} 55$

$2 \quad 2.8 \quad \mathrm{~V} 3, \mathrm{~V} 88$

$\begin{array}{lll}2 & 2.8 \quad \mathrm{~V} 103, \mathrm{~V} 140\end{array}$

$2 \quad 2.8 \quad \mathrm{~V} 12, \mathrm{~V} 59$ 


\begin{tabular}{|c|c|c|c|}
\hline $\begin{array}{l}\text { Yaşadığı sorunun nedenini } \\
\text { belirtmemiş }\end{array}$ & 2 & 2.8 & V78, V85 \\
\hline Toplam kod sayısı:10 & 71 & 100 & 68 \\
\hline
\end{tabular}

Tablo 2 incelendiğinde EBA'ya erişim kategorisinde 10 kod bulunmaktadır. Bu kategorideki kodlardan bazıları "EBA'ya giriş yapamama/bağlanma sorunu, sistem sorunu, internetin olmaması, canlı derse girememe" şeklindedir. Kodlara ilişkin örnek alıntlar:

"Bazen siteyi açamıyoruz canlı ders olduğunda derse de giremiyoruz" (V21). "İnternet konusunda sorun yaşamıyorum ama tek elektronik cihazımız olduğu için 4 çocuk olunca yetmiyor" (V55). "EBA'ya bağlantıda sorun çıkıyor" (V56).

Çocuklarının EBA'dan sınıf düzeyine göre hazırlanan dersleri, velilerin \%51.3'ü (76 veli) her gün, \%19.6'sı (29 veli) haftada 3-4 kez, \%17.6'sı (26 veli) arada sırada, \%8.1'i (12 veli) haftada 1-2 kez takip ederken \%3.4'ü (5 veli) hiç takip etmediğini belirtmiştir. Yani, velilerin görüşlerine göre çocukların yarısından fazlası dersleri her gün takip etmektedir. Çocuklarının uzaktan eğitimi nasıl almasını tercih ettikleri sorulduğunda, velilerin \%72.3'ü (107 veli) “Çocuğumun kendi öğretmenleri tarafından canlı yayınlarla” \%52.7'si (78 veli) “Çocuğumun kendi öğretmenleri tarafından kaydedilmiş videolarla” \%22.3'ü (33 veli) “MEB'in belirlediği öğretmenler tarafından canlı yayınlarla" \%10.1'i (15 veli) "MEB'in belirlediği öğretmenler tarafından kaydedilmiş videolarla" şeklinde belirttikleri görülmüştür. Bu çalışmada velilerin çoğunlukla canlı yayın ya da kaydedilmiş video üzerinden çocuklarının kendi öğretmenleri tarafından eğitim verilmesini tercih ettikleri görülmüştür.

Çocukların dersleri takip etmede istekli olma durumları velilere sorulduğunda \%59.5'inin (88 veli) orta düzeyde, \%23'ünün (34 veli) çok, \%12.8'inin (19 veli) az istekli oldukları ve \%4.7'sinin (7 veli) hiç istekli olmadığı görülmüştür. Buna göre çocukların dersleri istekli bir şekilde takip etme durumlarının orta düzeyde olduğu sonucuna ulaşılabilir. Velilerin çocuklarının uzaktan eğitim derslerine verdikleri tepkileri değerlendirmesine ilişkin kodlar Tablo 3'te verilmiştir. 
Tablo 3.

Velilerin çocuklarının uzaktan eğitim derslerine verdikleri tepkileri değerlendirmesi

2.Kategori: Velilerin çocuklarının uzaktan eğitim derslerini izlerken gösterdikleri tepkilerini değerlendirmeleri

\begin{tabular}{lccl} 
Kodlar & f & $\%$ & Katılımcllar \\
\hline İlgili /istekli & \multirow{2}{*}{$34 \quad 22.0$} & V6, V17, V20, V34, V38, V41, V56, V57, \\
& & & V62, V66, V67, V68, V69, V71, V81, \\
& & V85, V86, V87, V89, V93, V94, V98, \\
& & & V100, V102, V104, V106, V111, V116, \\
& & V120, V124, V129, V130, V133, V144
\end{tabular}

Katılımcl/sorulara cevap verme $24 \quad 15.5 \quad$ V2, V4, V6, V8, V16, V32, V37, V39, V42, V45, V47, V50, V61, V74, V76, V78, V90, V95, V99, V109, V110, V119, V125, V139

Değișkenlik gösteriyor

Dikkatli bir şekilde

dinleme/izleme

İlgisiz/isteksiz

Dikkatini verememe

Sıkılıyor

Ciddiye almıyor

Pasif dinleyici
$21 \quad 13.5$ V11, V12, V14, V15, V22, V24, V25, V33, V53, V60, V72, V84, V92, V97, V112, V114, V122, V141, V142, V146, V148

2012.9 V3, V5, V8, V21, V31, V47, V50, V61, V65, V70, V73, V76, V82, V91, V107, V125, V128, V135, V145, V147

1912.3 V1, V9, V10, V13, V27, V29, V35, V58, V63, V64, V77, V80, V101, V108, V113, V115, V121, V137, V143

159.7 V36, V43, V44, V49, V51, V59, V96, V103, V117, V123, V126, V127, V134, V136, V140

$5 \quad 3.2 \quad$ V40, V54, V88, V105, V132

$3 \quad 1.9 \quad$ V48, V52, V55

$31.9 \quad \mathrm{~V} 23, \mathrm{~V} 30, \mathrm{~V} 83$ 


\begin{tabular}{lccl}
\hline $\begin{array}{l}\text { Uzaktan eğitime yabancılık } \\
\text { çekme/kendi ögretmenini } \\
\text { arama }\end{array}$ & 2 & 1.3 & V18, V19 \\
$\begin{array}{l}\text { İlk zamanlarda ilgiliydi ancak } \\
\text { sonra ilgisi azaldı }\end{array}$ & 2 & 1.3 & V7, V131 \\
Boş & 7 & 4.5 & V26, V28, V46, V75, V79, V118, V138 \\
Toplam kod sayısı:12 & 155 & 100 & 148 \\
\hline
\end{tabular}

Tablo 3 incelendiğinde velilerin çocuklarının uzaktan eğitim derslerini izlerken gösterdikleri tepkilerini değerlendirmeleri kategorisinde 12 kod bulunmaktadır. $\mathrm{Bu}$ kategorideki kodlardan bazıları "İlgili/istekli, katılımcı/sorulara cevap verme, değişkenlik gösteriyor, dikkatli bir şekilde dinleme/izleme, ilgisiz/isteksiz, dikkatini verememe" şeklindedir. Kodlara ilişkin örnek alıntılar:

“Çok istek olmuyor çünkü alıştığı bir ortam değil film izler gibi izliyor sıkılıyor çok ilgisini çekmiyor" (V19). "Dersi dikkatli bir şekilde dinleyip sorulan soruları istekli bir şekilde cevaplandırlyor." (V76). "Bazen çok istekli bir şekilde ders dinliyor bazen ise isteksiz olabiliyor." (V148).

Velilere çocuklarıyla birlikte uzaktan eğitim derslerini takip etme durumları sorulduğunda \%79.7'sinin (118 veli) evet cevabına karşılık \%20.3'ünün (30 veli) hayır cevabını vermiştir. Buna göre velilerin büyük çoğunluğunun çocuklarıyla birlikte dersleri takip ettiği görülmüştür.

Uzaktan eğitim sürecinde çocukların kendi öğretmeninin destek olup olmadığı verilere sorulduğunda \%88.5'i (131 veli) evet, \%11.5'i (17 veli) hayır cevabını vermiştir. Velilerin görüşlerine göre sınıf öğretmenlerinin neredeyse tamamının pandemi sürecinde öğrencilerine destek olduğu söylenebilir. Çocukların kendi öğretmenleri tarafından sağlanan destekle ilgili velilerin görüşlerine ait kodlar Tablo 4'te verilmiştir. 
Tablo 4 .

Çocukların kendi öğretmeni tarafından sağlanan destek ile ilgili velilerin görüşleri

3.Kategori: Çocukların kendi öğretmeni tarafından sağlanan destek

$\begin{array}{llll}\text { Kodlar } & \text { f } & \% & \text { Katılımcılar }\end{array}$

Ödev

$78 \quad 37.3$ V2, V4, V5, V6, V7, V8, V9, V11, V12,

V13, V14, V15, V16, V17, V18, V19,

V22, V24, V26, V27, V28, V34, V39,

V42, V44, V45, V47, V52, V56, V57,

V59, V60, V66, V75, V78, V84, V87,

V88, V89, V90, V91, V92, V93, V94,

V95, V96, V97, V100, V102, V103,

V104, V106, V108, V109, V110, V112,

V113, V116, V117, V119, V120, V121,

V123, V126, V127, V128, V130, V131,

V132, V133, V134, V138, V140, V141,

V142, V144, V147, V148

Veliyle iletişim kurarak çocuğu 35 takip etme
35

16.7

\section{$\mathrm{V} 25$}

V64, V68, V73, V76, V78, V81, V82 V90, V106, V114, V122, V125, V126, V127, V130, V134, V135, V138, V141, V146

Ders videoları, ders notları, pdf, $\quad 26$ görsel ses kaydı gönderme

$12.5 \mathrm{~V} 2, \mathrm{~V} 7, \mathrm{~V} 8, \mathrm{~V} 10, \mathrm{~V} 23, \mathrm{~V} 32, \mathrm{~V} 33, \mathrm{~V} 47$, V48, V50, V56, V58, V59, V89, V91, V98, V101, V103, V108, V109, V117, V123, V134, V138, V146, V147

Etkinlik hazırlama

115.3 V7, V19, V26, V34, V90, V93, V95, V124, V127, V131, V138,

Kitap okuma

104.8 V33, V51, V97, V102, V103, V107, V108, V112, V117, V144,

Canlı yayın

94.3 V1, V12, V41, V60, V66, V105, V127, V128, V143 


\begin{tabular}{|c|c|c|c|}
\hline $\begin{array}{l}\text { İhtiyaç halinde destek ve } \\
\text { yönlendirme }\end{array}$ & 9 & 4.3 & $\begin{array}{l}\text { V20, V35, V38, V43, V70, V83, V136, } \\
\text { V137, V145 }\end{array}$ \\
\hline Motive etme & 6 & 2.9 & V40, V51, V99, V118, V131, V146 \\
\hline Boş & 8 & 3.8 & $\begin{array}{l}\text { V49, V62, V74, V85, V111, V115, V129, } \\
\text { V139 }\end{array}$ \\
\hline Destek sağlamama & 17 & 8.1 & $\begin{array}{l}\text { V29, V30, V31, V46, V53, V54, V61, } \\
\text { V63, V65, V67, V69, V71, V72, V77, } \\
\text { V79, V80, V86 }\end{array}$ \\
\hline Toplam kod sayısı:10 & 209 & 100 & 148 \\
\hline
\end{tabular}

Tablo 4 incelendiğinde çocukların kendi öğretmeni tarafından sağlanan destek kategorisinde 10 kod bulunmaktadır. Bu kategorideki kodlardan bazlları "Ödev, veliyle iletişim kurarak çocuğu takip etme, ders videoları, ders notları, pdf, görsel, ses kaydı gönderme, etkinlik hazırlama" şeklindedir. Kodlara ilişkin örnek alıntılar:

"Çok destek olmakta, etkinlikler yaptırmakta, çok ilgili elinden gelenin fazlasını yapmaktadır" (V124). "Öğretmenimiz canlı ders yapıyor, ödev kontrolleri, ek ödevler, test çözümleri yapıyor" (V128). "Öğretmenimiz öğrencileri ile bağını hiç kesmedi sürekli ilgileniyor ses kaydı, video, pdf dosyaları, deneme sinavları, önemli günlerin etkinlikleri gibi birçok desteği var" (V138).

Velilerin çocuklarına uzaktan eğitim sürecinde kendileri tarafından sağlanan destek ile ilgili görüşlerine ait kodlar Tablo 5'te verilmiştir. 
Tablo 5.

Velilerin çocuklarına uzaktan eğitim sürecinde kendileri tarafından sağlanan destek ile ilgili görüşleri

\begin{tabular}{|c|c|c|c|}
\hline Kodlar & $\mathrm{f}$ & $\%$ & Katılımcilar \\
\hline $\begin{array}{l}\text { Derslerini, ödevlerini yaparken } \\
\text { yardımcı olma/teşvik etme }\end{array}$ & 58 & 31.9 & $\begin{array}{l}\text { V7, V8, V9, V11, V13, V15, V20, V22, } \\
\text { V24, V25, V27, V28, V29, V30, V33, } \\
\text { V37, V38, V39, V40, V45, V49, V51, } \\
\text { V52, V55, V56, V57, V58, V60, V64, } \\
\text { V70, V78, V79, V80, V88, V90, V91, } \\
\text { V92, V93, V95, V96, V99, V100, V102, } \\
\text { V103, V107, V108, V110, V112, V113, } \\
\text { V117, V122, V127, V130, V131, V137, } \\
\text { V138, V144, V145 }\end{array}$ \\
\hline
\end{tabular}

Anlamadığı konulara yardımcı $24 \quad 13.2$ V2, V3, V5, V6, V12, V13, V33, V41, olma V47, V54, V60, V61, V76, V89, V98, /eksikliklerini tamamlama V99, V103, V108, V112, V122, V128, V142, V145, V146

Kitap okumasına destek olma

$1910.5 \mathrm{~V} 4, \mathrm{~V} 8, \mathrm{~V} 10, \mathrm{~V} 15, \mathrm{~V} 18, \mathrm{~V} 19, \mathrm{~V} 22, \mathrm{~V} 33$, V35, V44, V52, V53, V59, V65, V74, V117, V131, V139, V144

Birlikte EBA haricinde ders

$14 \quad 7.7$ V13, V17, V29, V48, V63, V68, V71, videoları izleme V82, V94, V101, V106, V135, V141, V147

Test yaptırma/soru çözdürme

$13 \quad 7.2$ V1, V19, V21, V31, V42, V65, V66, V76, V90, V123, V134, V139, V148

Okul ortamı gibi planlı

94.9 V14, V16, V43, V54, V67, V72, V73, çalışmasını sağlama V83, V119

Kendimi yetersiz

94.9 V23, V62, V77, V97, V115, V116, V118, hissetme/destek olamama V120, V126 


\begin{tabular}{|c|c|c|c|}
\hline Etkinlikler ve oyunla eğitim & 8 & 4.4 & $\begin{array}{l}\text { V10, V17, V25, V44, V78, V91, V93, } \\
\text { V143 }\end{array}$ \\
\hline Ders anlatma & 7 & 3.8 & $\begin{array}{l}\text { V84, V104, V109, V114, V133, V134, } \\
\text { V140 }\end{array}$ \\
\hline Kaynak kitap alma & 7 & 3.8 & V46, V50, V56, V87, V111, V121, V136 \\
\hline Boş & 14 & 7.7 & $\begin{array}{l}\text { V26, V32, V34, V36, V69, V75, V81, } \\
\text { V85, V86, V105, V124, V125, V129, } \\
\text { V132 }\end{array}$ \\
\hline Toplam kod sayısı:11 & 182 & 100 & 148 \\
\hline
\end{tabular}

Tablo 5 incelendiğinde velilerin çocuklarına uzaktan eğitim sürecinde kendileri tarafından sağlanan destek kategorisinde 11 kod bulunmaktadır. Bu kategorideki kodlardan bazıları "Derslerini ve ödevlerini yaparken yardımcı olma/teşvik etme, anlamadığı konulara yardımcı olma/eksikliklerini tamamlama, birlikte EBA haricinde ders videoları izleme, kendini yetersiz hissetme/destek olamama” şeklindedir. Kodlara ilişkin örnek alıntılar:

"Sürekli takip ediyorum beraber dersi dinliyoruz. Dikkat etmesi gereken yerlerde uyarıyorum, bilmediği yerlerde artı ben de dersi dinlediğim için oğlumla birlikte öğreniyorum anlayamadığı yerlerde anlatıyorum" (V13). "Kaynak kitapları alarak düzenli bir şekilde EBA'yı takip ederek günlük normal okul saatindeki gibi ders programlarına uyarak" (V14). "Öğretmen kadar olmasa da yardımcı oluyoruz ama kendimi yetersiz buluyorum" (V115).

Velilere pandemi sürecinde çocuğunuza eğitim hangi yolla verilsin diye sorulduğunda \%76.4'ünün (113 veli) yüz yüze eğitim, \%19.6'sının (29 veli) hem uzaktan hem yüz yüze eğitim cevabını verirken \%4.1'inin (6 veli) uzaktan eğitim yoluyla eğitim verilmesini tercih ettiklerini belirtmişlerdir. Bu çalışmada velilerin büyük çoğunluğunun yüz yüze eğitim verilmesini tercih ettikleri görülmektedir.

Uzaktan eğitim sürecinin öğrenci açısından avantajları ile ilgili velilerin görüşlerine ait kodlar Tablo 6'da verilmiştir. 
Tablo 6.

Uzaktan eğitim sürecinin öğrenci açısından avantajları ile ilgili velilerin görüşleri

5. Kategori: Uzaktan eğitim sürecinin öğrenci açısından avantajları

$\begin{array}{llll}\text { KodlarV6 } & \text { f } & \% & \text { Katılımclar }\end{array}$

Avantajı yok

Zaman-mekân bağımsızlı̆̆ı

Eğitimin sürekliliği

Çocuğun kendisine ve ailesine ayırdığı zamanın artması

Teknolojinin eğitimde

kullanımının önemi

Tekrar yapma olanağı

Okulun kıymetini anlama

Boş

Toplam kod sayısı:8
5033.8 V1, V5, V8, V16, V19, V21, V22, V30, V31, V32, V34, V36, V40, V41, V46, V61, V62, V63, V65, V66, V71, V79, V83, V86, V87, V88, V92, V95, V96, V98, V102, V104, V106, V107, V110, V111, V113, V115, V116, V118, V122, V124, V126, V131, V134, V135, V137, V143, V144, V146

$2919.6 \quad V 7, V 11, V 12, V 15, V 18, V 20, V 24, V 25$, V27, V33, V42, V43, V48, V51, V52, V53, V54, V55, V60, V70, V74, V82, V84, V93, V101, V140, V141, V147, V148

$24 \quad 16.2$ V2, V10, V17, V23, V35, V44, V45, V47, V57, V58, V68, V80, V81, V85, V94, V99, V100, V109, V117, V119, V127, V130, V138, V139

$18 \quad 12.2$ V4, V9, V13, V39, V54, V56, V59, V72, V73, V103, V105, V112, V120, V123, V125, V128, V133, 145

$96.1 \quad \mathrm{~V} 28, \mathrm{~V} 38, \mathrm{~V} 50, \mathrm{~V} 67, \mathrm{~V} 77, \mathrm{~V} 90, \mathrm{~V} 91$, V108, V121

96.1 V3, V37, V64, V76, V78, V89, V97, V136, V142

$2 \quad 1.3 \quad$ V6, V14

$7 \quad 4.7 \quad V 26, V 29$, V49, V69, V75, V129, V132

$148 \quad 100 \quad 148$ 
Tablo 6 incelendiğinde uzaktan eğitim sürecinin öğrenci açısından avantajları kategorisinde 8 kod bulunmaktadır. Bu kategorideki kodlardan bazıları "Avantajı yok, zaman-mekân bağımsızlığı, eğitimin sürekliliği, çocuğun kendisine ve ailesine ayırdığı zamanın artması, teknolojinin eğitimde kullanımının önemi, tekrar yapma olanağı" şeklindedir. Kodlara ilişkin örnek alıntılar:

"Uzaktan eğitimin çocuklar açısından avantajı zaman kavramı içerisinde rahat hareket etmeleridir. Örn. vaktinde izleyemedikleri dersin tekrarını izlemeleri gibi" (V15). "Televizyonun ve telefonun eğitim için faydalı olabileceğini anladılar" (V108). "Cocuklar öğretmenlerine alışık oldukları için evde bu süreci yönetmek zor. Öğrenciye kattığı bir avantaj yok diye düşünüyorum" (V146).

Velilerin uzaktan eğitim sürecinin kendileri açısından avantajları ile ilgili görüşlerine ait kodlar Tablo 7'de verilmiştir.

Tablo 7.

Velilerin uzaktan eğitim sürecinin kendileri açısından avantajları ile ilgili görüşleri

6. Kategori: Velilerin uzaktan eğitim sürecinin kendileri açısından avantajları

Kodlar $\quad$ f $\quad \% \quad$ Katılımcllar

Avantajı yok

$53 \quad 35.8$ V1, V5, V8, V9, V10, V12, V14, V16, V18, V19, V23, V31, V34, V35, V40, V42, V46, V52, V53, V57, V63, V65, V69, V71, V77, V78, V79, V83, V86, V87, V88, V96, V97, V100, V102, V106, V111, V113, V115, V116, V118, V123, V126, V131, V133, V134, V135, V136, V138, V143, V144, V146, V147,

Çocuğunun derse olan ilgisini ve $23 \quad 15.5 \quad$ V4, V15, V22, V25, V27, V33, V36, V37, yeterliliğini gözlemleme V38, V39, V51, V64, V66, V67, V76, V84, V90, V92, V93, V121, V128, V139, V140

Çocuğunun hep yanında $15 \quad 10.2$ V6, V20, V24, V41, V54, V55, V56, V61, olması/gözünün önünde olması V62, V82, V94, V99, V104, V105, V122

Öğreniyorum-öğretiyorum

117.4 V13, V17, V28, V29, V44, V47, V58, V73, V91, V132, V145 


\begin{tabular}{|c|c|c|c|}
\hline $\begin{array}{l}\text { Çocuğunun sağlıklı ve güvende } \\
\text { olması }\end{array}$ & 11 & 7.4 & $\begin{array}{l}\text { V60, V68, V74, V81, V107, V109, V112, } \\
\text { V117, V124, V137, V141 }\end{array}$ \\
\hline $\begin{array}{l}\text { Ebeveyn olarak çocuğa daha } \\
\text { fazla vakit ayırma }\end{array}$ & 10 & 6.8 & $\begin{array}{l}\text { V26, V43, V45, V59, V103, V114, V120, } \\
\text { V125, V139, V148 }\end{array}$ \\
\hline $\begin{array}{l}\text { Çocuğunun derslerden geri } \\
\text { kalmamasının veliyi mutlu } \\
\text { etmesi }\end{array}$ & 8 & 5.4 & $\begin{array}{l}\text { V2, V3, V11, V32, V85, V89, V98, V101, } \\
\text { V130, V142 }\end{array}$ \\
\hline Ekonomik olması & 4 & 2.7 & V7, V48, V55, V72 \\
\hline Okul telaşının olmaması & 4 & 2.7 & V67, V70, V95, V110, V127 \\
\hline $\begin{array}{l}\text { Öğretmenlerin yaşadığı } \\
\text { zorlukları daha iyi anlama }\end{array}$ & 1 & 0.7 & V108 \\
\hline Boș & 8 & 5.4 & $\begin{array}{l}\text { V21, V30, V49, V50, V75, V80, V119, } \\
\text { V129 }\end{array}$ \\
\hline Toplam kod sayısı:11 & 148 & 100 & 148 \\
\hline
\end{tabular}

Tablo 7 incelendiğinde velilerin uzaktan eğitim sürecinin kendileri açısından avantajları kategorisinde 11 kod bulunmaktadır. Bu kategorideki kodlardan bazıları "Avantajı yok, çocuğunun derse olan ilgisini ve yeterliliğini gözlemleme, çocuğunun hep yanında olması/gözünün önünde olması, öğreniyorum-öğretiyorum, çocuğunun sağlıklı ve güvende olması" şeklindedir. Kodlara ilişkin örnek alıntılar:

"Ben ilkokul mezunuyum. Önceden birlikte ödev yaparken konuyu bilmediğim için anlamaya çalışıyordum, çok vaktimi alıyordu. Şimdi birlikte dersi dinliyoruz ben anlıyorum konuyu bildiğim için hemen anlamadığı yerleri anlatıyorum kendisi yapıyor yapamadı̆̆ı yerlerde yine yardımcı oluyorum" (V13). "Çocuğum hep yanımda, gözümün önünde bunun için mutluyum" (V54). "Sağlıklı, güvende olmasını bilmek" (V141).

Uzaktan eğitim sürecinin öğrenci açısından dezavantajları ile ilgili velilerin görüşlerine ait kodlar Tablo 8'de verilmiştir. 
Tablo 8.

Uzaktan eğitim sürecinin öğrenci açısından dezavantajları ile ilgili velilerin görüşleri

7.Kategori: Uzaktan eğitim sürecinin öğrenci açısından dezavantajları

$\begin{array}{llll}\text { Kodlar } & \text { f } & \% & \text { Katılımclar }\end{array}$

Öğretmeninden ve

arkadaşlarından uzak olması

Yüz yüze eğitim gibi verimli ve kalıcı olmaması

Okuldan uzaklaşma/disiplinsizlik/tatilde gibi hissetme/

Odaklanamaması ve motive olamaması

Etkileşimin olmaması/soru soramama /dönüt alamama

Dersleri anlayamama

Dezavantajı yok

Evde oldukları için sıkılmaları

Ders süresinin kısa olması
$24 \quad 14.5$ V24, V28, V37, V47, V52, V80, V85, V87, V94, V95, V96, V102, V104, V110, V111, V112, V124, V127, V130, V136, V140, V141, V144, V146

3018.1 V3, V6, V15, V20, V23, V34, V39, V50, V51, V55, V61, V66, V67, V73, V82, V84, V103, V107, V108, V109, V114, V120, V125, V132, V137, V138, V145, V146, V147, V148

$22 \quad 13.3 \quad V 9, \mathrm{~V} 11, \mathrm{~V} 40, \mathrm{~V} 42, \mathrm{~V} 45, \mathrm{~V} 55, \mathrm{~V} 60, \mathrm{~V} 68$, V70, V78, V88, V93, V94, V107, V116, V121, V122, V125, V128, V131, V133, V136

$21 \quad 12.7$ V1, V21, V25, V29, V33, V36, V43, V44, V46, V48, V54, V57, V59, V76, V86, V100, V115, V117, V121, V126, V140

159.0 V19, V26, V27, V31, V38, V53, V64, V66, V68, V72, V74, V92, V123, V126, V142

$14 \quad 8.4$ V10, V13, V15, V16, V32, V41, V54, V71, V86, V98, V105, V113, V134, V143

127.2 V17, V18, V35, V58, V65, V69, V81, V90, V118, V119, V129, V135

$6 \quad 3.6 \quad V 4$, V22, V56, V78, V91, V131

$5 \quad 3.0 \quad \mathrm{~V} 2, \mathrm{V7}, \mathrm{V} 66, \mathrm{~V} 89, \mathrm{~V} 99$ 


\begin{tabular}{lccl}
\hline Okula özlem & 5 & 3.0 & V12, V14, V101, V109, V139 \\
Boş & 12 & 7.2 & $\begin{array}{l}\text { V5, V8, V30, V49, V62, V63, V75, V77, } \\
\text { V79, V83, V97, V106 }\end{array}$ \\
& & & \\
Toplam kod sayısı: 11 & 166 & 100 & 148 \\
\hline
\end{tabular}

Tablo 8 incelendiğinde uzaktan eğitim sürecinin öğrenci açısından dezavantajları kategorisinde 11 kod bulunmaktadır. Bu kategorideki kodlardan bazıları “Öğretmeninden ve arkadaşlarından uzak olması, yüz yüze eğitim gibi verimli ve kalıcı olmaması, okuldan uzaklaşma/disiplinsizlik/tatilde gibi hissetme, odaklanamaması ve motive olamaması, etkileşimin olmaması/soru soramama/dönüt alamama" şeklindedir. Kodlara ilişkin örnek alıntılar:

"Arkadaşlarından ve öğretmenlerinden uzak kalmaları öğrenciler açısından bir dezavantajdır" (V103). "Yeterince anlamadığı konuyu öğretmenine soramaması ve tam anlamda derslerine odaklanamaması" (V126). "Yüz yüze eğitimin sağladığı avantajlardan mahrum kaldı. Sosyalleşmesi adına büyük bir engel oldu" (V146).

Velilerin uzaktan eğitim sürecinin kendileri açısından dezavantajları ile ilgili görüşlerine ait kodlar Tablo 9'da verilmiştir.

Tablo 9.

Velilerin uzaktan eğitim sürecinin kendileri açısından dezavantajları ile ilgili görüşleri

8. Kategori: Velilerin uzaktan eğitim sürecinin kendileri açısından dezavantajları

Kodlar $\quad$ f $\% \quad$ Katılımcllar

Uzaktan eğitimle çocuğunun verimsiz eğitim aldığını

düşünme

Dezavantajı yok

28

18.4

18.4

V6, V7, V11, V21, V31, V42, V46, V47, V48, V54, V58, V61, V62, V70, V71, V82, V85, V86, V98, V99, V100, V104, V107, V111, V112, V124, V126, V141,

2818.4 V15, V16, V17, V18, V25, V26, V28, V32, V35, V38, V39, V63, V64, V65, V68, V69, V74, V76, V81, V89, V90, V91, V110, V118, V125, V129, V135, V139 


\begin{tabular}{|c|c|c|c|}
\hline Velinin sorumluluğunun artması & 26 & 17.1 & $\begin{array}{l}\text { V9, V12, V13, V14, V19, V27, V34, V36, } \\
\text { V49, V53, V56, V57, V72, V77, V78, } \\
\text { V83, V96, V101, V108, V122, V132, } \\
\text { V133, V134, V136, V140, V146, }\end{array}$ \\
\hline $\begin{array}{l}\text { Çocuğuna eğitimsel açıdan } \\
\text { yetememe hissi }\end{array}$ & 25 & 16.5 & $\begin{array}{l}\text { V3, V22, V23, V37, V44, V50, V59, V66, } \\
\text { V67, V73, V87, V92, V93, V94, V95, } \\
\text { V102, V105, V109, V115, V123, V128, } \\
\text { V138, V143, V144, V145, }\end{array}$ \\
\hline Çocuğu motive edememe & 9 & 5.9 & $\begin{array}{l}\text { V1, V4, V29, V60, V84, V103, V121, } \\
\text { V131, V142, }\end{array}$ \\
\hline $\begin{array}{l}\text { Çocuğuyla arasında psikolojik } \\
\text { açıdan sorunların oluşması }\end{array}$ & 8 & 5.3 & $\begin{array}{l}\text { V40, V41, V51, V55, V88, V93, V116, } \\
\text { V131 }\end{array}$ \\
\hline Çocuğun sıkılması & 7 & 4.6 & $\begin{array}{l}\text { V24, V52, V88, V113, V114, V117, } \\
\text { V147 }\end{array}$ \\
\hline Çocuğun sürekli evde olması & 7 & 4.6 & V2, V20, V43, V119, V120, V137, V148 \\
\hline Velinin öğretmen rolünü alması & 6 & 3.9 & V10, V33, V45, V51, V127, V130, \\
\hline Boş & 8 & 5.3 & V5, V8, V30, V75, V79, V80, V97, V106 \\
\hline Toplam kod sayısı: 10 & 152 & 100 & 148 \\
\hline
\end{tabular}

Tablo 9 incelendiğinde velilerin uzaktan eğitim sürecinin kendileri açısından dezavantajları kategorisinde 10 kod bulunmaktadır. Bu kategorideki kodlardan bazıları "Uzaktan eğitimle çocuğunun verimsiz eğitim aldığını düşünme, dezavantajı yok, velinin sorumluluğunun artması, çocuğuna eğitimsel açıdan yetememe hissi, çocuğu motive edememe, velinin öğretmen rolünü alması" șeklindedir. Kodlara ilişkin örnek alıntılar:

"Evde düzen kalmıyor tüm yük aileye yükleniyor, sürekli çocuğun dersi ile ilgilenmesi gerekiyor" (V19). "Olumsuz yanı benim için onları ders yapmaya teşvik etmek ve her biri ile öğretmenin ilgilendiği şeyleri bile üstlenmek ciddi anlamda zorluyor ev hanımlığından öğretmenliğe geçmiş durumdayım" (V33). "Velinin evde de sorumlulukları çok fazla ve birden çok öğrencisi ve çocuğu olan veli çocuklarının eğitimleriyle tam anlamıla ilgilenemiyor" (V49). 


\section{SONUÇ, TARTIŞMA VE ÖNERİLER}

Covid-19 pandemi sürecinde uzaktan eğitim, yüz yüze eğitimin yerini almıştır. Bu süreçte ilkokul öğrencileri için EBA aracılığıyla yürütülen uzaktan eğitim faaliyetleriyle ilgili velilere büyük sorumluluk düşmektedir. Okul ortamından uzak kalan öğrencilere okul disiplinini sağlama konusundaki en büyük görevi veliler üstlenmektedir. Bu süreçte velilerin çocuklarının eğitimine destek olmanın ötesinde öğretmen rolünü üstlendikleri söylenebilir. Bu amaçla bu çalışmada ilkokul öğrencilerinin aldıkları uzaktan eğitimle ilgili velilerin görüşleri alınmıştır.

Velilerin görüşlerine göre EBA'ya erişim konusunda çocukların EBA'ya giriş yapamama, bağlanma sorunu, sistem sorunu, canlı derse girememe gibi teknik problemlerin yanı sıra velilerin teknolojik bilgi eksikliği ve internet bağlantılarının olmaması gibi sorunları yaşadıkları belirlenmiştir. Öğrencilerin uzaktan eğitimle ilgili yaşadıkları sorunlara bakıldığında uzaktan eğitimde internet bağlantısı (Karakaş ve Doğan, 2017), sistem sorunları (Özyürek, Bedge, Yavuz ve Özkan, 2016), sisteme giriş yapamama (Çoskunserçe ve İşçitürk, 2019), ders esnasında öğrencileri sistemden atma (Tüysüz ve Çümen, 2016) gibi sorunların yaşandığı görülmektedir. Alan yazında ortaya çıkan sonuçlara paralel olarak pandemi sürecinde yürütülen uzaktan eğitimle ilgili yapılan bu çalışmada ilkokul öğrenci velilerinin EBA'ya erişim konusunda ifade ettikleri sonuçlar benzerlik göstermektedir. Telli Yamamoto ve Altun (2020) uzaktan eğitimle ilgili öğrencilerin teknolojik bilgi eksikliğinden dolayı sorun yaşadıklarını belirtmişlerdir. Bu çalışmada da velilerin kendilerinin teknolojik bilgi eksikliğinden dolayı ilkokula giden çocuklarına teknolojik olarak yeterince destek olamamalarından kaynaklı olarak uzaktan eğitimde sorun yaşadıkları sonucuna ulaşılmıştır.

Velilere göre pandemi sürecinde EBA ile sunulan uzaktan eğitim derslerini izlerken çocukların genel olarak ilgili, istekli oldukları ve dersleri dikkatli bir şekilde izledikleri fakat bazı velilere göre çocukların isteksiz oldukları ve dikkatlerini veremeyip sıkıldıkları bildirilmiştir. Ayrıca veliler çocuklarının uzaktan eğitime yabancılık çektiklerini ve kendi öğretmenlerinin eksikliğini yaşadıklarını ifade etmişlerdir. Benzer şekilde öğrencilerin uzaktan eğitimle yürütülen derslerle ilgili olarak iletişime girememe, dönüt alamama, odaklanamama, dikkat dağınıklığı, derslerin sıkıcı olması ve uzaktan eğitime karşı kendilerini yabancı hissetme durumları önceki çalışmalarda belirtilmiştir (Yılmaz ve Güven, 2015; Özgöl, Sarıkaya ve Öztürk, 2017; Atasoy ve Yiğitcan Nayir, 2019). Fakat şurası bir gerçek ki pandemi sürecinde uzaktan eğitim, eğitimdeki süreklilik için olmazsa olmazımızdır. Bu sebeple özellikle salgın sürecinde bu tür dezavantajların önüne geçebilecek birtakım yenilikler gerektiğinden eğitimin en önemli kavramlarından olan etkileşim, motivasyon ve dönüt gibi faktörleri geliştirebilecek tedbirler alınmalıdır.

Çocuklarının uzaktan eğitimle verilen derslerdeki isteklilik durumları ile ilgili velilerin verdiği cevaplara paralel olarak Tuluk ve Akyüz'ün (2019) belirttiği gibi çocuklar EBA'ya yönelik yeterli motivasyona sahip değildir. Bu durum EBA üzerinden yürütülen uzaktan eğitimle ilgili öğrencilerin inançlarıyla ilgilidir. Dolayısıyla öğrencilerdeki isteksizlik durumu onların öğrenme ile ilgili eksiklik yaşayacakları durumunu beraberinde 
getirmektedir. Çocuklardaki motivasyon eksiklikleri İbicioğlu ve Antalyalı'nın (2005) belirttiği gibi öğrencilerin başarılarını olumsuz etkilemektedir. Veliler öğretmenlerin pandemi sürecinde destek olmak için herhangi bir mecburiyetleri olmamasına rağmen ödev verme, sürekli iletişim halinde olma, ders videoları, ders notu, pdf, görsel, ses kaydı gönderme gibi destek verdiklerini ifade etmişlerdir. Velilerin kendilerinin de çocuklarına uzaktan eğitim sürecinde ödevlerini yaparken yardımcı olma, eksikliklerini tamamlama, birlikte EBA haricinde ders videoları izleme şeklinde destek oldukları belirtilmiştir. Uzaktan eğitimde öğretmen, veli ve öğrenci iş birliğinin yararlı olacağı alan yazında bildirilmiştir (Çakmak ve Taşkıran, 2017). Sonuç olarak bu salgın sürecinde öğretmenlerin ve velilerin öğrencilere destek olarak onları derse teşvik etme, motive etme konusundaki çabaları öğrencilerde yaşanan motivasyon kaybını engelleyebilir.

Uzaktan eğitimin zaman-mekân bağımsızlığı olanağı sunması (Tüysüz ve Aydın, 2007; Gümüş ve Fırat, 2016; Özgöl, Sarıkaya ve Öztürk, 2017; Cabı, 2018; Paydar ve Doğan, 2019, Sezer ve Korucu, 2019) ve derslerin tekrar izlenebilmesi (Tüysüz ve Çümen, 2016; Çakmak ve Taşkıran, 2017; Özgöl, Sarıkaya ve Öztürk, 2017; Cabı, 2018) gibi avantajlarının olduğu bilinmektedir. Bu çalışmada uzaktan eğitimin zaman-mekân kavramlarını ortadan kaldırdığı, pandemi sürecinde eğitime süreklilik kazandırdı̆̆ı, çocuklara tekrar yapma olanağı sağladığı çoğu veli tarafından bildirilmiştir. Buna rağmen velilerden bazılarının çocukları için uzaktan eğitimin bir faydası olmadığını düşündüğü de görülmüştür.

Pandemi sürecinde çocuklarına sunulan uzaktan eğitimin velilere göre dezavantajları; çocuklarının öğretmeninden ve arkadaşlarından uzak kalmaları, okuldan uzaklaşmaları nedeniyle disiplinsizliğe alışmaları, motivasyon eksikliği yaşamaları, soru sorup dönüt alamamaları ve uzaktan eğitimin yüz yüze eğitimin yerini verimlilik açısından tutamayacağı şeklinde belirtilmiştir. Bahsedilen bu dezavantajlar alan yazında pandemiden önce yapılan uzaktan eğitim sürecinde yaşanan sorunlarla tutarlılık göstermektedir (Cabı, 2018; Sezer ve Korucu, 2019; Özgül ve Uysal, 2016; Yılmaz ve Güven, 2015, Paydar ve Doğan, 2019; İbicioğlu ve Antalyall, 2005; Şahin vd. 2017). Velilerin bahsettikleri bu sorunlar uzaktan eğitimde etkileşim eksikliğinden kaynaklanıyor olabilir (Özgül ve Uysal, 2016). Oysa ki etkileşimli ders videolarının öğrencilerin motivasyonunu artırdığı, konuyu daha iyi öğrenmelerini sağladığı ve dikkatlerini daha çok öğrenme ortamına verdikleri sonucuna ulaşılmıştır (Koçdar, Karadeniz, Bozkurt ve Büyük, 2017). Öğrenci ön bilgileri dikkate alınarak, dersler örneklerle pekiştirilerek, dönüt verilerek ve etkileşim ortamı sağlanarak uzaktan eğitim daha etkili bir hale getirilebilir (Yalçın İncik, Topçu ve Yağlığlu, 2018). Bu sebeple uzaktan eğitimin asenkron şeklinde değil de senkron olarak yapılması ve uzaktan eğitimde etkileşim faktörünün ön plana alınması önem arz etmektedir.

Çocukların okul ortamından uzak kaldığı pandemi sürecinde velilerin çoğunluğu tarafından çocuklara eğitimsel destek sağlanmaktadır. Fakat bazı velilerin kendilerini çocuklarına destek olma konusunda yetersiz hissettiklerini ifade ettikleri görülmüştür. Velilere göre uzaktan eğitimin kendileri açısından dezavantajları sorulduğunda; uzaktan 
eğitimle çocuğunun verimsiz bir şekilde eğitim aldığını, sorumluluklarının arttığını, çocuğunun eğitimine destek olma konusunda verimli olamadıklarını hatta pandemi sürecinde çocukla arasında psikolojik sorunlar yaşadıklarını ifade ettikleri görülmüştür. Covid-19 sebebiyle başlatılan Evde Kal sürecinde çocukların sürekli evde olmaları nedeniyle sıkıldıkları ve velilerin onları motive etmekte zorlandıkları veliler açısından belirtilen dezavantajlar arasındadır. Bazı velilerin öğretmen rolü üstlenmelerini dezavantaj olarak gördükleri de çalışmanın farklı sonuçlarından birisidir. Bu sonuçlara göre pandemi sürecinde velilerin öğretmen rolü alarak çocuklarıyla eğitim faaliyetlerini sürdürürken zorlandıkları söylenebilir.

Velilere göre uzaktan eğitimin kendileri açısından avantajları sorulduğunda; çoğunluğu uzaktan eğitimin hiçbir avantajının olmadığını belirtmekle birlikte bazı veliler çocuğunun yeterliliğini daha iyi gözlemleyebildiğini, bu salgın sürecinde çocuğunun yanında olmasının, sağlıklı ve güvende olmasının avantaj sağladığını, ebeveyn olarak çocuğuna daha fazla zaman ayırabildiği şeklinde ifade etmişlerdir. Velilerin pandemi sürecinde çocuklarının yüz yüze eğitime devam etmek yerine uzaktan eğitime başlanmasının çocuklarının sağlığı açısından daha önemli olduğunu vurguladıkları söylenebilir. Ancak çocuklarının eğitimi için velilerin büyük çoğunluğunun (\%76.4) yüz yüze eğitimi, hatta uzaktan eğitim verilse dahi yüz yüze eğitimle birlikte verilmesini (\%19.6) tercih ettiği görülmüştür. Velilerin sadece küçük bir oranının (\%4.1) uzaktan eğitimi tercih ettiği görülmektedir. Bu çalışmada velilerin görüşlerine benzer olarak önceki çalışmalarda öğrencilerin genellikle yüz yüze eğitimi tercih ettikleri (Özyürek, Begde, Yavuz ve Özkan, 2016) ve haftada az ders saati olsa da yüz yüze eğitim almak istedikleri (Özgöl, Sarıkaya ve Öztürk, 2017) görülmektedir. Özturan, Egeli ve Darcan (2000) uzaktan eğitimle yüz yüze eğitimin desteklenerek verilmesi gerektiğini belirtmişlerdir. Ancak bazı çalışmalarda bilginin kalıcılığı (Balaman, 2018) ve başarı açısından (Ünal, 2017) iki yöntem karşılaştırıldığında uzaktan eğitimin yüz yüze eğitime göre daha etkili olduğu görülmüştür. Velilerin yüz yüze ve uzaktan eğitimle ilgili tercihlerinin sebebi bu ortamların hangisinin daha etkili olabileceğiyle ilgili bilgi eksikliğinden veya uzaktan eğitime aşina olmamalarından kaynaklanıyor olabilir. Veliler çocukları için yüz yüze eğitimi tercih ettiklerini belirttikleri gibi bunun yanı sıra pandemi sürecinde çocuğunun yanında ve sağlıklı olmasını ifade etmeleri önemlidir. Yaşanan pandemi sürecinde çocukların sağlıklı olmaları ve eğitimde süreklilik sağlanması için uzaktan eğitimin bir gereklilik olduğu söylenebilir.

$\mathrm{Bu}$ çalışmanın sonuçlarına bağlı olarak aşağıdaki öneriler verilebilir:

- Uzaktan eğitim, özellikle etkileşimin sağlanabilmesi için çocukların kendi öğretmenleri tarafından canlı yayınlarla eş zamanlı olarak sürdürülmelidir.

- Çocuklara pandemi sürecinde uzaktan eğitimin bir gereklilik olduğu hissettirilmelidir.

- Sosyalleşme problemlerine karşın sanal sınıflar oluşturulup çocukların sınıf arkadaşlarıyla ve öğretmenleriyle iletişim kurabilmelerine imkân sağlanmalıdır. 
- Uzaktan eğitimde öğrencilerin motivasyonunu artırıcı etkinliklere yer verilmeli, dönüt alması ve etkileşim kurması sağlanmalıdır.

- 2020-2021 eğitim-öğretim yılında uzaktan eğitimin sürdürülmesi gerekirse; eğitimin sürekliliğinin ve verimliliğin sağlanması, öğrencilerin kendilerini tatil ortamında hissetmeleri gibi durumların önüne geçilebilmesi için uzaktan eğitimin zorunlu bir eğitim süreci olarak sürdürülmesi gerekmektedir.

- Uzaktan eğitimin başarılı bir şekilde yürütülebilmesi için öğretmen, öğrenci ve veli iş birliği ön plana alınmalıdır. Sınıf öğretmenleri, pandemi sürecinde çocukların eğitimine yardımcı olma hususunda özellikle kendisini yetersiz hisseden veliler başta olmak üzere bütün velilere destek olmalıdır.

\section{Kaynaklar}

Arslan, F. ve Korkmaz, Ö (2019). İlahiyat lisans tamamlama uzaktan eğitim öğrencilerinin etkileşim kaygıları ve uzaktan eğitime dönük tutumları. Ahmet Keleşoğlu Eğitim Fakültesi Dergisi, 1(1), 12-25.

Atasoy, M. ve Yiğitcan Nayir, Ö. (2019). Eğitim bilişim ağı (EBA) video modüllerinin matematik dersinde kullanımına ilişkin öğrenci görüşleri. Uluslararası Bilim ve Eğitim Dergisi 2(1), 24-37.

Balaman, F. (2018). Web tabanlı uzaktan eğitim ile geleneksel eğitimin internet programcllı̆ı 2 dersi kapsamında karşılaştırılması. Itobiad: Journal of the Human ve Social Science Researches, $7(2) \cdot 1173-1200$

Barış, M. F. (2015). Üniversite öğrencilerinin uzaktan öğretime yönelik tutumlarının incelenmesi: Namık Kemal Üniversitesi örneği. Sakarya University Journal of Education, 5(2), 36-46.

Bilgiç, H. G. ve Tüzün, H. (2015). Yükseköğretim kurumları web tabanlı uzaktan eğitim programlarında yaşanan sorunlar. Açıköğretim Uygulamaları ve Araştırmaları Dergisi, 1(3), 2650.

Cabı, E. (2018). Uzaktan eğitim ile bilgisayar okuryazarlığı öğretimi: Eğitmen deneyimleri. Başkent University Journal of Education, 5(1), 61-68.

Coşkunserçe, O. ve İşçitürk, G. B. (2019). Eğitim bilişim ağı (EBA) platformu hakkında öğrencilerin farkındalığının artırılmasına yönelik bir durum çalışması. Eğitimde Nitel Araştırmalar Dergisi, $7(1), 260-276$.

Çakmak, Z. ve Taşkıran, C. (2017). Sosyal bilgiler öğretmenlerinin perspektifinden eğitim bilişim ağı (EBA) platformu. Uluslararası Türk Eğitim Bilimleri Dergisi, 2017(9), 284-295.

Dinçer, S. (2006). Bilgisayar destekli eğitim ve uzaktan eğitime genel bir bakış. Akademik Bilişim Kongresi, 9-11 Şubat, Pamukkale Üniversitesi, Denizli.

Eren, A. ve Kaya, M. D. (2017). Üniversite öğrencilerinin uzaktan eğitim sistemine bakış açılarının teknoloji kabul modeli ile incelenmesi. Yüzüncü Yıl Üniversitesi Sosyal Bilimler Enstitüsü Dergisi, 1(35).

Ergün, E. ve Kurnaz, F. B. (2017). Çevrimiçi öğrenme ortamlarında sınıf topluluğu hissi ve öğrenci bağlılığı arasındaki ilişki. Kastamonu Eğitim Dergisi, 25(4), 1515-1532. 
Gül, İ. ve Arabacı, İ. B. (2018). Uzaktan eğitimle öğrenim gören eğitim yönetimi yüksek lisans öğrencilerinin programa ilişkin görüşleri. Sosyal Bilimler Araştırmaları Dergisi, 8(1) 79-88.

Gülbahar, Y. ve Karataş, E. (2016). Uzaktan öğretimi uzaktan eğitim yöntemi ile öğrenmek: "Eeğitmen sertifika programı". Kastamonu Eğitim Dergisi, 24(4), 1867-1880.

Gümüş, M. ve Fırat, M. (2016). Açık ve uzaktan öğrenmenin tercih edilme nedenlerinin belirlenmesi. Açıköğretim Uygulamaları ve Araştırmaları Dergisi, AUAd, 2(4), 158-168.

İbicioğlu, H. ve Antalyalı, Ö. L. (2005). Uzaktan eğitimin başarısında imkân algı motivasyon ve etkileşim faktörlerinin etkileri: karşılaştırmalı bir uygulama. Cukurova Üniversitesi Sosyal Bilimler Enstitüsü Dergisi, 14(2), 325-338.

Karaçorlu, A. T. ve Atıcı, B. (2019) Platformundaki kavram haritaları ve infografiklerin kullanımına dair öğretmen ve öğrenci görüşleri. Gazi Eğitim Bilimleri Dergisi, 5, 77-96.

Karakaş, H. ve Doğan, A. (2017). Sınıf öğretmenlerinin sınıfta kullandıkları bilgi iletişim teknolojilerine yönelik olumsuz tutumları ve yaşadıkları sorunlar. Hitit Üniversitesi Sosyal Bilimler Enstitüsü Dergisi, 10(1), 629-654.

Kaysi, F. ve Aydemir, E. (2017). Uzaktan eğitim süreçlerindeki etkileşim boyutlarının değerlendirilmesi. Sosyal Bilimler Dergisi, 4 (11), 778-790.

Koçdar, S., Karadeniz, A., Bozkurt, A. ve Büyük, K. (2017). Açık ve uzaktan öğrenmede sorularla zenginleştirilmiş etkileşimli video kullanımı. Eskişehir Osmangazi Üniversitesi Sosyal Bilimler Dergisi 18(2), 93-113.

McMillan, J. H. (2012). Educational Research Fundamentals for the Consumer (6th Ed.) Boston: Pearson.

Miles, M. B. ve Huberman, A. M. (1994). An Expanded Sourcebook Qualitative Data Analysis (2nd Ed.). London: Sage Publications.

Özgöl, M., Sarıkaya, İ. ve Öztürk, M. (2017). Örgün eğitimde uzaktan eğitim uygulamalarına ilişsin öğrenci ve öğretim elemanı değerlendirmeleri. Yükseköğretim ve Bilim Dergisi/Journal of Higher Education and Science 7(2), 294-304.

Özgül, E. ve Uysal, Ö. (2016). Uzaktan yaz okuluna yönelik öğrenci görüşleri. Açıköğretim Uygulamaları ve Araştırmaları Dergisi, 2(3), 130-150.

Özturan, M., Egeli, B. ve Darcan, O. (2000). Türk üniversitelerinde bilgisayar ağlarının uzaktan eğitim aracı olarak kullanılmasına ilişkin bir araştırma. Hacettepe Üniversitesi Eğitim Fakültesi Dergisi, 18(18), 108-113.

Özyürek, A., Begde, Z., Yavuz, N. F. ve Özkan, I. (2016). Uzaktan eğitim uygulamasının öğrenci bakış açısına göre değerlendirilmesi. Karabük Üniversitesi Sosyal Bilimler Enstitüsü Dergisi, 6(2), 592605.

Paydar, S. ve Doğan, A. (2019). Öğretmen adaylarının açık ve uzaktan öğrenme ortamlarına yönelik görüşleri. Eğitim ve Teknoloji, 1(2), 154-162.

Saklan, H. ve Ünal, C. (2019). Dijital eğitim platformları arasında EBA'nın yeri ile ilgili fen bilimleri öğretmenlerinin görüşleri. Ondokuz Mayıs Üniversitesi Eğitim Fakültesi Dergisi, 38(1), 19-34.

Savaș, A. C. ve Hamamcl, Z. (2010). Okullarda rehberlik hizmetlerinin internet üzerinden yürütülmesine ilişkin veli, öğrenci ve psikolojik danışmanların görüşlerinin incelenmesi. Pamukkale Üniversitesi Eğitim Fakültesi Dergisi, 27(27), 147-158.

Sezer, C. ve Korucu, A. T. (2019). Bilişim teknolojileri ve yazılım dersinde öğrenme yönetim sistemi kullanımının öğrenci akademik başarısına etkisi. Gazi Eğitim Bilimleri Dergisi, 5, 146-165. 
Smaldino, S. E., Lowther, D. L., Mims, C. ve Russell, J. D. (2015) Uzaktan eğitimde öğrenmeyi gerçekleştirme A. Arı (Ed.) ve S. M. ÖZDEMIR, M. CEYLAN (Çev.) Öğretim teknolojileri ve öğrenme araçları içinde (ss. 213-255). Eğitim Yayınevi: Konya (Orijinal yayın tarihi, 2014).

Şahin, L. Y., Karadağ, N., Bozkurt, A., Doğan, E., Kılınç, H., Uğur, S., Gümüş, S., Öztürk, A. ve Güler, C. (2017). Uzaktan eğitimde oyunlaştırma kullanımı: Oyunlaştırılmış web tabanlı bir alıştırma uygulaması. Turkish Online Journal of Qualitative Inquiry (TOJQI) 8 (4), 372-395.

Şentürk, H. (2020). Milli eğitimde DYK kurslarının uzaktan eğitim yoluyla yürütülmesine yönelik incelenmesi. Anadolu Üniversitesi Eğitim Fakültesi Dergisi (AUJEF), 4(1), 50-66.

Tanrıkulu, F. (2017). EBA'nın Türkçe dersi öğrenme alanlarını karşılama yeterliliğine yönelik öğretmen görüşleri. Ana Dili Eğitimi Dergisi, 5(3), 395-416.

Taşlıbeyaz, E., Karaman, S. ve Göktaş, Y. (2014). Öğretmenlerin uzaktan hizmet içi eğitim deneyimlerinin incelenmesi. Ege Eğitim Dergisi, 15(1), 139-160.

Telli Yamamoto, G. ve Altun, D. (2020). Coronavirüs ve çevrimiçi (online) eğitimin önlenemeyen yükselişi. Üniversite Araştırmaları Dergisi, 3(1), 25-34.

Tuluk, G. ve Akyüz, H. İ. (2019) Öğretmen ve öğretmen adaylarının EBA içerik incelemesi: 5. sınıf sayılar alt öğrenme alanı doğal sayılar ünitesi. Uşak Üniversitesi Sosyal Bilimler Dergisi, 12(2), $32-47$.

Tüysüz, C. ve Aydın, H. (2007). Web tabanlı öğrenmenin ilköğretim okulu düzeyindeki öğrencilerin tutumuna etkisi. Pamukkale Üniversitesi Eğitim Fakültesi Dergisi, 22(22), 73-78.

Tüysüz, C. ve Çümen, V. (2016). EBA ders web sitesine ilişkin ortaokul öğrencilerinin görüşleri. Uşak Üniversitesi Sosyal Bilimler Dergisi, 9(27/3), 278-296.

Ünal, B. B. (2017). Web tabanlı uzaktan eğitimin fen bilimleri konularında öğrenci başarısına etkisi. Uluslararası Türk Eğitim Bilimleri Dergisi, 2017 (9), 481-490.

Yalçın İncik, E., Topçu, Y. G. ve Yağlıoğlu, A.O. (2018). Uzaktan eğitim programlarında öğrenim gören öğrencilerin bu programlara ilişskin görüşleri (Mersin Üniversitesi Meslek Yüksekokulu Örneği). 2nd International Congress on Multidisciplinary Studies/II. Uluslararası Multidisipliner Çalışmalar Kongresi, Adana/Türkiye

Yıldırım, A. ve Şimşek, H. (2013). Sosyal Bilimlerde Nitel Araştırma Yöntemleri. (Genişletilmiş 9. Baskı). Ankara: Seçkin Yayıncılık.

Yılmaz, G. K. ve Güven, B. (2015). Öğretmen adaylarının uzaktan eğitime yönelik algılarının metaforlar yoluyla belirlenmesi. Türk Bilgisayar ve Matematik Eğitimi Dergisi, 6(2), 299-322. 
Bu çalışma için etik kurul izni 22/05/2020 tarih ve 05 sayılı Kafkas Üniversitesi Rektörlüğü Sosyal ve Beşeri Bilimler Etik Kurulu Başkanlığı'ndan alınmıștır. 
